NBER WORKING PAPER SERIES

\title{
THE SIZE AND COMPOSITION OF WEALTH HOLDINGS IN THE UNITED STATES, ITALY, AND THE NETHERLANDS
}

\author{
Arie Kapteyn \\ Constantijn Panis \\ Working Paper 10182 \\ http://www.nber.org/papers/w10182
}

\author{
NATIONAL BUREAU OF ECONOMIC RESEARCH \\ 1050 Massachusetts Avenue \\ Cambridge, MA 02138 \\ December 2003
}

Both authors are at RAND, 1700 Main Street, Santa Monica, CA 90401; e-mail to $<$ kapteyn@rand.org $>$ or $<$ panis@rand.org>. This paper benefited greatly from the expert input of Rob Alessie and Luigi Guiso throughout the course of the conceptualization and analysis. We are also very grateful to Nicholas Souleles for his thoughtful comments and to Delia Bugliari for her excellent research support. This research was sponsored by the Department of Labor, Pension and Welfare Benefits Administration, under Contract J-9-P-70045. We thank Patricia Willis for her encouragement and support. The views expressed herein are those of the authors and not necessarily those of the National Bureau of Economic Research.

(C2003 by Arie Kapteyn and Constantijn Panis. All rights reserved. Short sections of text, not to exceed two paragraphs, may be quoted without explicit permission provided that full credit, including (C) notice, is given to the source. 
The Size and Composition of Wealth Holdings in the United States, Italy, and the Netherlands Arie Kapteyn and Constantijn Panis

NBER Working Paper No. 10182

December 2003

JEL No. D91, J14, J26

\section{$\underline{\text { ABSTRACT }}$}

This paper analyzes retirement saving and portfolio choice in the United States, Italy, and the Netherlands. While these countries enjoy roughly the same standard of living, they vary widely in their institutional organization of retirement income provisions. Building on extensions of the life cycle model, we derive hypotheses on the implications of institutional differences for wealth accumulation and portfolio composition. Examples of implications are that the ratio of net worth and gross wealth should be highest in Italy, that Dutch households should hold the lowest wealth levels at retirement and that the ownership of risky assets should be highest in the U.S. We investigate these and other hypotheses at both the macro and micro level and find that the data are generally consistent with the hypotheses.

Arie Kapteyn

RAND

1700 Main Street

Santa Monica, CA 90401

kapteyn@rand.org

Constantijn Panis

RAND

1700 Main Street

Santa Monica, CA 90401

panis@rand.org 


\section{Introduction}

This paper analyzes retirement saving and portfolio choice in the United States, Italy, and the Netherlands. In addition to relying on public retirement provisions, households prepare for retirement through tax-sheltered and after-tax savings. They may invest these funds in a wide variety of assets, including housing, stocks, bonds, savings accounts, etc. These asset types differ in their risk, return, and liquidity characteristics as well as in their fiscal treatment. Economic theory postulates that households allocate their portfolios according to their risk aversion, time horizon, uncertain out-of-pocket medical expenditures, income risk, informal (family) risk sharing arrangements, etc. While the literature has tested various parts of the theory, both testing and quantification of the theory are hampered by the fact that some of the major variables do not exhibit sufficient variation within a country to establish their relative importance for portfolio choice, or, more generally, for retirement saving and investment. This paper partially fills that gap by exploring three countries with widely varying institutional arrangements for retirement income.

Portfolio allocation behavior is important for a number of reasons (e.g., Bertaut and StarrMcCluer, 2000). Returns vary across asset types, so portfolio composition has important implications for the pace of wealth accumulation and the degree of retirement preparedness; risks vary across asset types, so portfolio composition has important implications for the distribution of retirement income; portfolio decisions illuminate how tax policy affects household spending and saving; portfolio decisions illuminate how macro variables (interest rates, stock prices, inflation, unemployment) affect household spending and saving; and understanding households' portfolio decisions may provide deeper insight into theories of consumption and saving behavior.

This paper is organized as follows. Section 2 poses a theoretical framework and briefly reviews the literature on the size and composition of the wealth holdings of the (nearly) retired. Section 3 highlights relevant aspects of the legal and institutional environments of the three countries under study. Section 4 describes the three countries' microdata that we use. Section 5 draws together the theoretical framework and the institutional differences to formulate four hypotheses about expected patterns in the microdata from the different countries. Section 6 presents the empirical analysis with particular emphasis on Section 5's hypotheses. Section 7 concludes.

\section{Theoretical Framework and Literature}

Our point of departure to study retirement savings is the life cycle hypothesis (LCH) formulated by Modigliani and Brumberg (1954). The basic tenet of the LCH is that rational consumers will try to smooth consumption over the life cycle in such a way that the marginal utility of consumption is equalized across periods. Since individuals usually have a life cycle income pattern that is inversely U-shaped (at young ages, earnings are modest but grow until roughly retirement, after which income declines), the life cycle pattern of wealth is also inversely U-shaped. In its simplest form, sometimes referred to 
as a 'stripped-down' version (Browning and Lusardi, 1996), the LCH fails to explain several well-known facts. Several extensions have therefore been introduced. These include the incorporation of uncertainty, bequest motives, borrowing constraints, precautionary motives, transaction costs associated with the reshuffling of portfolios, taxes, and lack of financial sophistication. We discuss several of these extensions below, in so far as they shed light on the portfolios of the (near-)retired. Our interest is primarily in the implications of institutional arrangements for individuals' wealth accumulation and profile.

\subsection{Retirement Income Replacement Rates and Wealth}

As documented below, the United States, Italy, and the Netherlands vary greatly in the fraction of pre-retirement income that is replaced by social security and private pensions. To illustrate the implications of varying replacement rates for wealth accumulation, we take a simple version of the $\mathrm{LCH}$ with time preference rates equal to the interest rate, a constant household composition, no uncertainty, no bequest motives, and no liquidity constraints. ${ }^{1}$ Consumers live until they are 85 years old (which is known with certainty). In that case the optimal consumption profile over one's life is flat, i.e., one should plan to spend the same amount of money each period. This amount should be chosen in such a way that wealth is zero at the time of death.

Figure 1 illustrates the implications for saving and wealth accumulation for two different levels of retirement annuity incomes. The income paths have been chosen in such a way that lifetime resources are equal, so that they both imply the same consumption level. Clearly, the income path with the less generous retirement income leads to more wealth accumulation. Thus, the theory in its simple form would imply that those households with relatively meager pension provisions would save the most.

Panel A: Different replacement rates

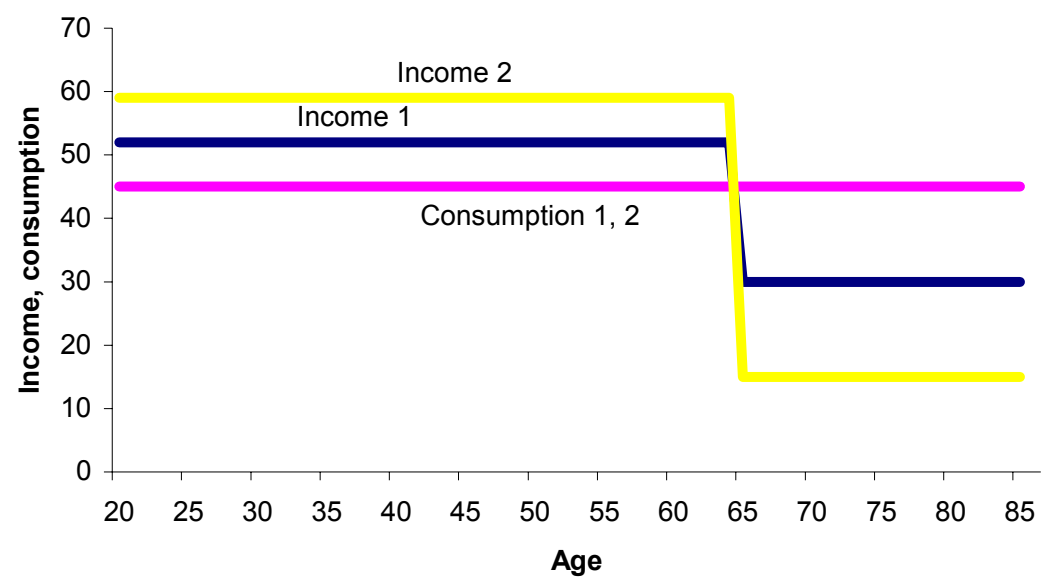

${ }^{1}$ The exposition is similar to illustrations by Bernheim, Skinner, Weinberg (2001). 
Panel B: Corresponding wealth paths

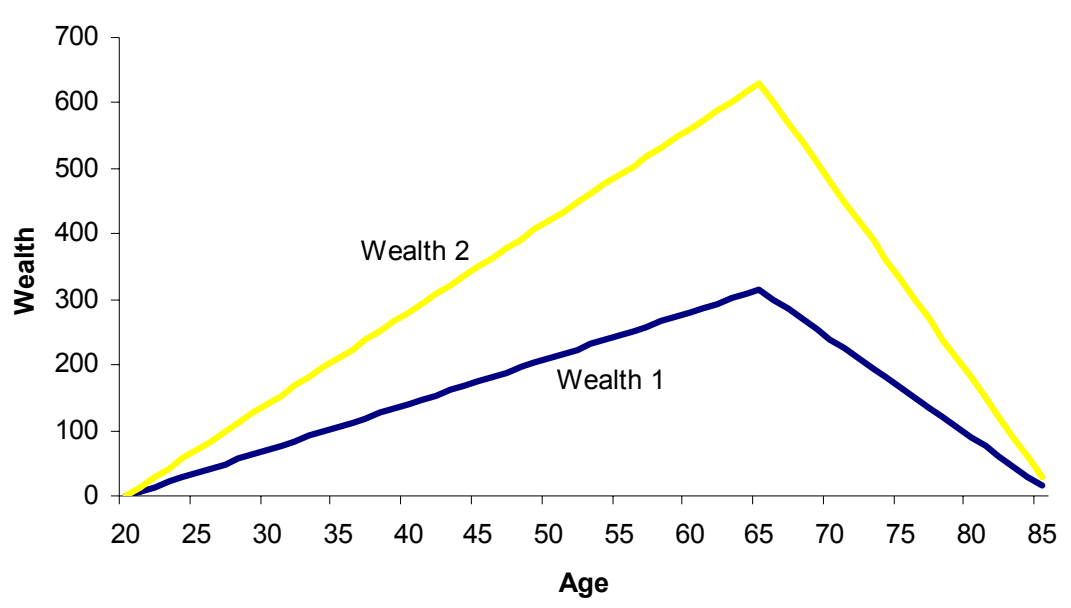

Figure 1. Income and Wealth Paths under Different Replacement Rates

\subsection{Precautionary Saving}

In its simplest form, the introduction of uncertainty leads to a straightforward extension of the LCH. Consumers still want to equalize the marginal utility of consumption across periods, but since they cannot control or foresee the future perfectly, they can now only equalize marginal utility in expectation. If in each period, the world would turn out to be exactly as expected, the expectation would be realized perfectly and we would be back in the world illustrated by, for instance, Figure 1. However, expectations are generally not realized exactly and on the basis of new information one has to re-optimize. For example, an unanticipated adverse income shock will lead to a revision of the consumer's expected income path over the life cycle, which in turn leads to a fall in consumption and a new trajectory for saving and wealth. Clearly, consumers would like to guard themselves against unpleasant surprises. An obvious strategy to do this is to save more as a matter of precaution. A vast literature has developed this so-called "precautionary saving motive".

The extent to which consumers increase their saving when facing future risk is governed by "prudence" (Kimball, 1990; Gollier, 2001). By definition, a consumer is prudent if adding a zero-mean risk to her future wealth raises her optimal saving. An example of a zero-mean risk would be one where a consumer's next year's endowment has an equal probability of being higher or lower with respect to a baseline by, say, $\$ 1,000$. Whether a consumer is prudent depends on her preferences. ${ }^{2}$ Consumers may not be prudent and hence will decrease saving if we make future financial resources more risky.

\footnotetext{
${ }^{2}$ To be precise, a necessary and sufficient condition for prudence is that an agent's marginal utility of future consumption is convex (Gollier, 2001, Proposition 60). Prudence is related to, but not the same as risk aversion. A consumer is prudent if absolute risk aversion is decreasing in wealth; in the special case of constant relative risk aversion, (relative) prudence is equal to (relative) risk aversion +1 .
} 
While there is no logical reason why consumers would have to increase saving in the face of increased future uncertainty, empirical work suggests that generally an increase in risk leads to more saving. The estimated sizes of precautionary saving vary considerably across studies (e.g., Dynan 1993; Guiso, Jappelli, Terlizesse, 1992; Lusardi 1997; Hubbard, Skinner, and Zeldes, 1994a, 1994b, 1995; Banks, Blundell, and Brugiavini, 2001).

\subsection{Liquidity Constraints and Wealth Accumulation}

Liquidity constraints can take various forms. The simplest form is a ceiling on the amount of money one can borrow. In many instances such a ceiling is not cast in stone and if one is willing to pay higher interest on the money borrowed, it is possible to increase the loan amount. More generally, the term "liquidity constraint" refers to the fact that borrowing rates are higher than lending rates. Liquidity constraints induce extra saving in several ways. The most straightforward case is where in a given period one would like to borrow, but cannot do so because of insufficient collateral or insufficient prospects of being able to pay back a loan in the future. However, even if a constraint is not binding in a given period (i.e., income is higher than planned expenditures), the fact that one may face liquidity constraints in the future may increase saving in the current period. In particular, liquidity constraints interact with income uncertainty since it increases the probability that adverse income shocks may necessitate the need to borrow in some future period.

The intuitive effect of liquidity constraints is that it shortens one's time horizon. Without liquidity constraints, the consumption effects of an adverse income shock in a given period may be spread out over many periods by borrowing money to pay for consumption in a given period and then reducing consumption in all subsequent periods by a little bit, rather than immediately cutting consumption by the total shortfall in income. This mechanism is known as time diversification and tends to reduce risk aversion (e.g., Gollier, 2001). If liquidity constraints are binding, the possibility to spread out the consumption shortfall over many periods is absent, or at least more limited, and this acts as a shortening of the time horizon with a resulting increase in risk aversion. The only way to reduce the risk of such a forced reduction in consumption is to save more. Savings then act as a "buffer stock" (Deaton, 1991; Carroll, 1992, 1997). Thus, liquidity constraints increase saving, even if they are not binding in the current period.

\subsection{Portfolio Composition and Saving}

Commonly in economic models, consumers are assumed to be risk-averse. That is, whenever a consumer is given a choice between a fixed amount of money and a gamble with expected payoff equal to the fixed amount, she will prefer the fixed amount. As a result of this, a risk-averse consumer will only be willing to invest some of her savings in a risky asset if the expected return of the risky asset is higher than of a riskless asset. The extent to which an individual is willing to invest in risky assets is determined by this individual's risk aversion. The literature distinguishes several measures of risk aversion, including coefficients of absolute and relative risk aversion. For the current discussion, 
the exact definitions of these risk aversion measures are of no great consequence. ${ }^{3}$ If a risky asset is available with an expected return larger than of an available riskless asset (e.g., putting money in a savings account), the standard theory predicts that an individual will always put some money into the risky asset. How much is put in the risky asset is a function of the risk aversion of the individual: the more risk-averse the agent is, the less she will put in the risky asset.

Since risky assets on average have a higher rate of return, it is of interest to know which people have the lowest risk aversion, as, on average, these are the people that will realize the highest return on their investment portfolio. On the other hand, even though the average return on risky portfolios is higher, this of course does not carry over to every individual portfolio and the higher riskiness implies a higher dispersion in outcomes than for less risky portfolios.

One "stylized fact" is that people with more wealth own more risky assets, such as stocks (e.g., Hochgürtel 1998, Barsky et al. 1997, Carroll 2001, Hurd 2001). Under reasonable assumptions on the form of the utility function, this is indeed predicted by the theory. The theory predicts that for risk-averse consumers an increase in wealth increases the amount of stocks if individuals have decreasing absolute risk aversion. However, following an increase in wealth, the share of risky assets may or may not increase. For the share to increase, relative risk aversion must decrease with wealth. The usual assumption is that it is constant, and thus the portfolio share should be independent of wealth. Empirically, the evidence is not clear-cut: evidence on relative risk aversion sometimes points at an increasing relationship to wealth (e.g., Guiso and Paiella, 2001); correlations between portfolio shares of risky assets and wealth are sometimes positive, consistent with decreasing relative risk aversion. However, a positive correlation between a risky asset portfolio share and wealth may also arise because of fixed portfolio management costs. Altogether, the relation between theory and the share of risky assets in total wealth is not yet clear-cut.

Given that we are interested in the size and composition of portfolios with which people reach retirement age, the natural context in which to consider risk aversion is intertemporal. That is, one should consider investments with an eye on their contribution to the financial resources at retirement. The first implication of that viewpoint is that young people should invest in a more risky way than older people. This is due to time diversification, i.e., the possibility for younger people to spread out any bad investment outcome over a longer period of their life. This supports the usual advice by financial planners to reduce exposure to risk when one gets older.

Another consequence of using an intertemporal framework is that we have to consider saving and investment decisions jointly. Consider a case where an individual can divide savings into riskless and risky assets (with higher expected return than the riskless asset).

\footnotetext{
${ }^{3}$ Formally, a utility function exhibits risk aversion if the function is concave. The degree of absolute risk aversion is defined as minus the ratio of the second derivative of the utility function and the first derivative. If we multiply this quantity by the argument of the utility function we obtain the degree of relative risk aversion.
} 
Will this individual save more than if only a riskless asset were available? This is relevant to assess the effects on saving decisions of financial innovation, such as the addition of new instruments. The answer depends on the structure of the individual's preferences, and in particular on this individual's prudence and risk aversion. If her prudence is sufficiently large relative to her risk aversion, the presence of a risky asset will increase saving. If not, the availability of a risky asset will reduce saving. ${ }^{4}$

To understand this result, recall that if a risky asset is available, an agent will always invest something in it. By investing something in the risky asset the total expected return on assets increases. In itself, the increase of resources in the future due to the higher expected return of the investment in the risky asset will lead to a fall in saving in the current period. However, also recall that precaution leads to more saving currently if uncertainty about the future goes up. The investment in the risky asset does exactly that: It increases uncertainty about the future. Whether the increase in current saving as a result of increasing future uncertainty dominates the fall in current saving as a result of the higher expected lifetime resources depends not only on the strength of the precautionary motive, but also on how much is invested in the risky asset. The more riskaverse the individual is, the smaller the amount she will invest in a risky asset. Thus, in the case of high risk aversion and small precaution, the investment in a risky asset will be modest with little effect on the amount of precautionary saving. Hence, current saving will fall as a result of higher expected future resources. In the opposite case of a strong precautionary motive and low risk aversion, a considerable amount will be invested in the risky asset; this increases uncertainty considerably and through a strong precautionary motive, this will lead to positive effect on current saving that dominates the negative effect caused by the increase in expected lifetime resources.

Which effect dominates empirically is a somewhat undecided issue, but under plausible assumptions about individual utility functions, it appears likely that the introduction of risky assets will decrease saving.

Of course, investment risk is not the only risk that affects consumption possibilities. Different people are exposed to different amounts and different kinds of risk and one would expect this to affect an individual's investment portfolio. Intuitively, one might think that when one is exposed to risk in one dimension, one becomes more averse to risk in another dimension. For instance, other things being equal, an individual with a very uncertain income may want to invest in a safer portfolio than someone whose income is virtually guaranteed. It turns out that such an effect of "background risk" on risk aversion will only hold if preferences satisfy certain logical conditions (Kimball, 1993; Gollier and Pratt, 1996; Gollier, 2001). Empirical work by Guiso, Jappelli, Terlizesse (1996) indicates that the presence of background risk lowers the willingness of households to hold risky assets. Similarly, Haliassos and Bertaut (1995) find that people in risky occupations are less likely to hold stocks. Using a self-reported measure of risk aversion, Guiso and Paiella (2001) find that the presence of background risk increases

\footnotetext{
${ }^{4}$ Saving will increase if and only if the degree of absolute prudence is larger than twice the degree of absolute risk aversion. See Gollier (2001).
} 
measured risk aversion. Thus, we tentatively conclude that individual preferences do satisfy the logical conditions for an increase in background risk to increase risk aversion.

As noted above, the presence of liquidity constraints works as if risk aversion increases. Guiso, Jappelli, Terlizesse (1996) indeed find some evidence that the presence of liquidity constraints reduces the demand for risky assets. Liquidity constraints may also have other implications for portfolio choice. For instance, if an individual faces borrowing ceilings this may induce her to hold more assets in liquid form than she would otherwise (Paxson, 1990).

Recall that if a risky asset (that pays a premium) is offered, a consumer will always invest something in it. This statement can be generalized to the case where one can choose from an array of risky assets. Unless the returns on these assets are perfectly correlated, an investor should have a portfolio that has at least a little of each. Of all the predictions of the theory, this is probably the one that is most clearly false. For example, a majority of households does not own any stock. One can think of various reasons why portfolios are incomplete, i.e., do not contain all assets. Haliassos and Bertaut (1995) list a number of reasons, including the cost of acquiring information about stocks, transactions costs (see also Vissing Jørgensen, 2000), minimum investment requirements, and deviations from the expected utility models underlying the $\mathrm{LCH}$. They find a strong effect of education, which suggests that stocks, being fairly complicated products, require a certain amount of knowledge that may be lacking in some parts of the population. This is supported by a finding by King and Leape (1998) that about 40 percent of the nonstockholders in their sample (of Canadian respondents) state that they did not know enough about the stock market.

Somewhat in line with the interpretation of these education effects, Benartzi and Thaler (2001) provide strong empirical evidence that portfolio choice may be a much less rational and forward-looking process than economic theory suggests. In particular, they provide evidence for what they call the " $1 / n$ strategy" among participants in defined contribution saving plans: participants tend to divide their contributions evenly across the funds offered in the plan. Thus the extent of stockholding may be expected to be influenced not only by the behavior of individual investors, but also by the behavior of institutions offering different investment options.

\subsection{Retirement Saving, Tax Incentives, Social Security, and Pensions}

Bernheim (1999) provides an excellent review of the literature on taxation and saving. Here we briefly touch on three important issues: (1) the saving effects of various forms of tax-deferred saving vehicles such as IRAs and 401(k)s, (2) the displacement effects of pensions and social security on private retirement saving, and (3) the effect of implicit taxes in income maintenance programs on saving behavior.

Theoretically, the effect of tax deferred saving vehicles on private saving is ambiguous. For instance by putting money into an IRA an individual avoids paying taxes on part of her income now, but will have to pay taxes on the money taken out of the IRA later. Not 
having to pay tax on the income put in an IRA amounts to an increase in the rate of return on saving. Such an increase in the rate of return has two effects. First, the higher return on the investment in an IRA makes it attractive to save, because it lowers the price of future consumption relative to the price of current consumption. Next to this "substitution effect" there is also an "income effect." The higher rate of return amounts to an increase in lifetime resources, which in itself raises current consumption, and hence lowers saving. In view of this theoretical ambiguity, empirical research has to settle the issue of the direction and the strength of the tax subsidy effect on private saving. Different researchers have reached very different conclusions. Authors such as Engen, Gale and Scholz (1996) find that these saving incentives have little or no effect, whereas others, notably Venti and Wise $(1990,1991,1995)$ find very substantial effects. Clearly the answer to the question of the effectiveness of saving incentives is very important in view of the total amount of taxes foregone as a result of these incentives.

One of the clear implications of the above graphical illustration of the $\mathrm{LCH}$ is that people should save more for retirement the lower their retirement income will be relative to their pre-retirement earnings. Conversely, the more generous pensions or social security income will be, the less incentive there is to save for retirement. This is known as the "displacement effect" of pensions and social security on private savings (Feldstein, 1974). Yet, empirical research has shown repeatedly that households with relatively generous pensions are also the households that save the most or at least do not save less than other households (e.g., Gustman and Steinmeier, 1998). However, this may simply reflect differences in tastes: some people have a stronger taste for saving than others. And those that do tend to both arrange for more generous pensions and to accumulate more private wealth. Assuming that on average the tastes for saving do not differ substantially across countries, a cross-country comparison should bear out that in countries with more generous old age pensions systems people save less than in countries with less generous systems. See below.

Government regulations may impose various implicit taxes on saving. A particularly important class of implicit taxes consists of asset-based means tests in various income maintenance programs, like Temporary Assistance to Needy Families (TANF), Medicaid, or Food Stamps. As a result, someone with low and uncertain income has a strong incentive not to save if income maintenance is asset-tested, because every time she experiences a bad income draw, she first has to run down her assets before qualifying for income support. She can maintain a higher consumption level on average by not saving and drawing income support if income falls below the cut-off point for qualification. Hubbard, Skinner, Zeldes (1994a, 1994b, 1995) show that a model incorporating these features along with uncertainty and liquidity constraints is able to reproduce the observed wealth distribution and its evolution over time quite well. 


\section{Legal and Institutional Environments}

Kapteyn and Panis (2002) provide a detailed discussion of legal issues and institutional features that affect retirement income in the United States, Italy, and the Netherlands. This section highlights the features that are relevant for our purposes. In separate subsections, we highlight the three legs of the proverbial retirement income stool: social security, occupational pensions, and private savings. ${ }^{5}$ We then discuss capital market imperfections (transaction costs and liquidity constraints) and exposure to financial risks in retirement.

\subsection{Social Security}

In the United States, social security is mainly provided as Old-Age and Survivors Insurance (OASI). ${ }^{6}$ It makes cash payments to retired workers, spouses of retired workers, and widows and children of deceased workers. A separate program, Supplemental Security Income (SSI), makes cash payments to, among others, needy elderly. The Italian social security program, Programma Nazionale di Sicurezza Sociale, makes cash payments to retired workers and widow(er)s of deceased workers; it also guarantees a minimum benefit for the poor. The Italian program does not have a spousal benefit. In the Netherlands, cash payments are made to elderly individuals - regardless of their work history — on the basis of the General Old-Age Act (Algemene Ouderdoms Wet, AOW). We use the term "social security" to refer to all programs that pay cash benefits to the elderly, regardless of whether the entitlement originates from contributive insurance or social assistance.

All three social security programs are predominantly funded on a pay-as-you-go (PAYG) basis. The United States maintains a buffer in the form of an OASI trust fund. There is no trust fund in Italy. Italian social security outlays currently exceed contributions by about 8-17 percent of payroll (Brugiavini 1999); the difference is funded from general tax revenues. The Netherlands instituted a trust fund in 1996.

In all three countries, participation in social security is mandatory, and coverage is nearly universal. Almost all elderly (are eligible to) receive some benefits.

Table 1 gives an indication of the generosity of social security in the three countries. The first column shows social security expenditures as a percentage of GDP. Italy spent approximately 15.7 percent of GDP on social security in 1999, far higher than the United

\footnotetext{
${ }^{5}$ Laws and institutions are changing continuously. As a general rule, we describe the status around the time of our household surveys, i.e., from roughly 1995 to 1999 , and note major changes over time only where relevant. All amounts are in 1998 currencies, unless stated otherwise. We converted all amounts in Dutch guilders (NLG) or Italian liras (ITL) into euros $(€)$ at the exchange rates that were irrevocably fixed at the euro's conceptual introduction in the beginning of 1999: $€ 1=$ NLG 2.20371 = ITL 1936.27. On $1 / 1 / 1999$ the exchange rate of the euro and the U.S. dollar $(\$)$ was $\$ 1=€ 0.857$. The dollar exceeded parity with the Euro for several years, but had declined to $\$ 1=€ 0.953$ by $1 / 1 / 2003$. For purposes of comparing purchasing power, an exchange rate of one-to-one is probably a reasonable approximation. ${ }^{6}$ Unless noted otherwise, our discussion does not extend to public support for the disabled and their dependents.
} 
States (3.9 percent in 2000) and the Netherlands (5.0 percent in 1999). This is in minor part explained by the age structure of its population. The second column shows the elderly dependency ratio, i.e., the size of the population that is at least 65 years old as a fraction of the working age population. Italy again tops the list, but the differences are not large. ${ }^{7}$ The third column shows the ratio of social security outlays as a fraction of GDP and the dependency ratio. It may be interpreted as a measure of the generosity of each country's social security program. Italy remains far above the other two countries. This is largely because occupational pensions, which play a significant role in the United States and the Netherlands, are negligible in Italy — see below. In addition, until recently, early retirement was very widespread in Italy, especially in the public sector. Several categories of public employees could retire after 15-20 years of contributions. Early retirement essentially increases the dependency ratio.

Table 1. Social Security Outlays and Dependency Ratios

\begin{tabular}{|l|c|c|c|}
\hline & $\begin{array}{l}\text { (1) Social security } \\
\text { outlays as percentage } \\
\text { of GDP (1999) }\end{array}$ & $\begin{array}{l}\text { (2) Population age 65+ } \\
\text { as percentage of pop'n } \\
\text { age 25-64 (1994) }\end{array}$ & $\begin{array}{l}\text { Ratio of } \\
\text { (1) and (2) }\end{array}$ \\
\hline United States & 3.9 & 24.8 & 0.156 \\
Italy & 15.7 & 29.6 & 0.523 \\
Netherlands & 5.0 & 24.4 & 0.208 \\
\hline
\end{tabular}

Sources: Board of OASI Trustees (2001), Social Security Administration (2000); Franco (2000); Kapteyn and De Vos (1999); Bureau of the Census (1996).

Social security benefits are paid in the form of a life-long annuity in all three countries.

In the United States, OASI benefits are a function of historical earnings, retirement age, and marital status. They may be claimed at age 62; delayed claiming results in higher benefits according to a schedule that is roughly actuarially fair. In 2001, average retired worker benefits were $\$ 845$ per month. Aged couples received an average of $\$ 1,410$ per month, and single elderly widow(er)s $\$ 811$. Benefits are adjusted annually for inflation. The replacement rate for unmarried individuals with average wages was approximately 44 percent. The nationwide average replacement rate, including spousal and other derived benefits, was approximately 56 percent in 1995 (Blöndal and Scarpetta, 1998). There is no minimum OASI benefit. However, regardless of their earnings history, elderly individuals (couples) are eligible for a monthly SSI benefit of \$530 (\$796).

In Italy, private sector workers may retire with full benefits at age 60 (men) or 55 (women) or after 35 years of social security tax payments, whichever is earlier. ${ }^{8}$ For

\footnotetext{
${ }^{7}$ Italy's fertility rate was very low during the 1990 s, well below the replacement level. While the dependence ratio is only somewhat larger in Italy than in the U.S. and the Netherlands, the difference is expected to increase markedly in the future.

${ }^{8}$ Italian social security benefit calculations changed materially in 1992 and, to a lesser extent, in 1995 . The changes will be phased in over a long period. Workers with at least 18 years of contributions in 1995 will receive benefits computed on the basis of the rules applying before the 1992 reform (Franco 2000). For purposes of our analysis, which focuses on individuals age 50 and older, the pre-1992 regime therefore applies.
} 
public sector employees, only 20 (men) or 15 (women) years of tax payments are required. Benefits are a function of number of years worked and so-called pensionable earnings. For private sector employees, pensionable earnings are equal to the average earnings of the last five years prior to retirement. (For public sector employees, pensionable earnings are based on the last paycheck only.) Pensionable earnings are converted into social security benefits by applying a 2 percent factor (referred to as the rate of return) for each year of social security tax payment up to a maximum of 40 years (Brugiavini 1999). A worker can thus get at most 80 percent of his pensionable earnings. Earnings that enter the calculation of pensionable earnings are capped. Benefits are therefore also capped, at approximately $€ 6,000$ per month in 2000 . Contributions are not subject to any maximum. There is no actuarial adjustment for retirement age. ${ }^{9}$ There are no spousal benefits in Italy. However, the entire benefit becomes payable to a surviving spouse upon death of the retiree. The benefit is never lower than a means-tested minimum benefit of approximately $€ 370$ per month in 2000 . A substantial fraction of retirees receive this minimum benefit. Benefits are adjusted regularly for nominal wages.

In the Netherlands, social security benefit rules are very simple. Earnings history does not play a role: the benefits are almost exclusively a function of marital status and residency history. In 2001, unmarried individuals age 65 or older receive $€ 883$ per month; married couples with both spouses at least age 65 receive $€ 1,206$ per month. Married couples with one spouse below age 65 receive between $€ 603$ and $€ 1,206$, depending on the younger spouse's income (Social Insurance Bank 2000). The eligibility age is 65 and there is no provision for early retirement. ${ }^{10}$ There is no link between labor force participation and entitlement to social security. The full benefits apply to residents who have lived their entire working life (age 15-64) in the Netherlands; benefits are reduced by 2 percent for every year spent abroad (Kapteyn and De Vos, 1999). Benefits are adjusted annually for nominal wage growth.

Table 2. Contribution and Replacement Rates

\begin{tabular}{|l|r|c|c|c|}
\hline & \multicolumn{3}{|c|}{ Contribution rate (\% of taxable income) } & $\begin{array}{c}\text { Average } \\
\text { replacement } \\
\text { rate }\end{array}$ \\
\hline & Employer & Employee & Total & 56.0 \\
United States & 5.26 & 5.26 & 10.52 & 80.0 \\
Italy & 18.93 & 8.34 & 27.27 & 45.8 \\
Netherlands & 0.00 & 17.90 & 17.90 & \\
\hline
\end{tabular}

Source: Blöndal and Scarpetta (1998)

Table 2 summarizes social security contribution rates and average replacement rates for the three countries. The replacement rates are the average over four scenarios and may therefore differ from the average nationwide replacement rates. ${ }^{11}$

\footnotetext{
${ }^{9}$ The 1992 and 1995 reforms made fundamental changes to benefit calculations. Benefits are now uncapped but progressive and there is an actuarial adjustment for retirement age. On average, the new rules will reduce benefits by 27-29 percent (Beltrametti 1996; Rostagno 1996).

${ }^{10}$ Occupational pensions often offer bridge benefits between the (early) retirement age and age 65 .

${ }^{11}$ The replacement rates are computed as averages of four scenarios: two earnings levels (average and two third of average) and two household compositions (single worker and worker with a dependent spouse).
} 


\subsection{Occupational Pensions}

Occupational pensions are retirement income schemes that are sponsored by employers. The United States, Italy, and the Netherlands vary widely in the role of occupational pensions. They are widespread, well funded, and generous in the Netherlands; largely immaterial for most Italians (except for so-called severance pay arrangements, see below); and at roughly equal footing with social security in the United States. Table 3 shows pension assets as a percentage of GDP, the fraction of retirees with any pension benefits, and the fraction of the working population that is covered by a pension plan.

Table 3. Importance of Occupational Pensions (Late 1990s)

\begin{tabular}{|l|c|c|c|}
\hline & $\begin{array}{c}\text { Funds } \\
\text { (\% of GDP) }\end{array}$ & $\begin{array}{c}\text { Percent of retirees } \\
\text { receiving pension }\end{array}$ & $\begin{array}{c}\text { Percent working } \\
\text { pop'n covered }\end{array}$ \\
\hline Italy & Negligible & Negligible & 0.02 \\
Netherlands & 118 & 76 (men) 23 (women) & 90 \\
U.S. & 66 & 48 (men) 26 (women) & 44 \\
\hline
\end{tabular}

Source: Johnson (1999)

Traditionally, employer-sponsored pensions in the United States have been of the defined benefit (DB) type. The plans are specific to individual employers, not to industry groups such as is mostly the case in the Netherlands. ${ }^{12}$ Given that there are tens of thousands different plans, their features vary widely. Portability is very limited. The benefit is typically fixed in nominal terms upon job separation. An increasing fraction of DB plans - 64 percent in 1993 - offers the option of a lump sum distribution upon job separation (Scott and Shoven, 1996). Workers who take that option may leave the distribution tax-sheltered by investing it in an IRA or they may cash it out (Hurd, Lillard, and Panis, 1998).

In 1978, 38 percent of American workers were covered by a DB pension, compared to only 21 percent in 1997 (Department of Labor, 2001). Instead, defined contribution (DC) plans are becoming more widespread (up from seven percent in 1978 to 25 percent in 1997). Under DC plans, retirement income depends on the level of contributions and the rate of return earned on those contributions. Workers typically decide on the allocation on their plan balance and bear the investment risk.

In Italy, the social security program was traditionally intended to provide comprehensive retirement income. In light of its social security program's dire financial outlook, Italy established DC pension plans in 1992. These plans are still in their infancy. As of March 1999, only approximately 400,000 workers were enrolled in a DC plan and total assets

The earnings profile is assumed to be flat and earnings are revalued according to changes in average earnings. The rates refer to basic pensions, means-tested supplements, and mandatory occupational pensions only. See Blöndal and Scarpetta (1998).

12 The Pension Benefit Guaranty Corporation, a federal agency, guarantees pension payments to retirees whose pension plan ended. 
represented only 0.015 percent of GDP (Banca d'Italia, 1999). With few exceptions, there are no DB plans.

While not strictly a pension plan, so-called severance pay arrangements have long played an important role in Italian retirement income security. They are somewhat similar to DC plans, but are paid out upon job separation, regardless of age. Employers contribute 6.9 percent of workers' wages into a self-administered fund (Franco 2000). Workers earn a legally determined return on those funds of 1.5 percent plus three-fourths of the inflation rate. While this severance entitlement is accruing, the worker has a secure but uncollectable credit with his employer, who retains full discretionary powers over the funds (Franco, 2000). Upon job separation, there is a lump sum severance payment. Severance pay credits comprised 5.2 percent of household financial wealth in 1997 (authors' calculations, based on the 1998 Survey of Household Income and Wealth).

In the Netherlands, occupational pensions are widespread and large. Plans are organized by industry sectors and administered by industrial organizations. Virtually all pensions are DB pensions. They are easily ported across employers. If a worker's previous and new employers belong to the same industrial organization, portability is merely an administrative issue. If the employers belong to different industrial organizations, the plan administrators settle internally such that the previous administrator disburses a lump sum to the new administrator. The employee receives credit for accumulated pension rights as part of the new pension. ${ }^{13}$ All benefits are paid in the form of a lifelong annuity; lump sum distributions upon job termination are not allowed.

Table 4. After-Tax Median Replacement Rates

\begin{tabular}{|l|c|}
\hline Country & Replacement rate \\
\hline Italy & 75 \\
Netherlands & 91 \\
U.S. & 41 \\
\hline
\end{tabular}

Source: Gruber and Wise (1999)

Of course, what matters for individual households is the combined replacement rate resulting from the combination of social security and occupational pensions. Table 4 provides an estimate of the after tax replacement rates in the three countries for a "typical" (median) household. Clearly, the replacement rate is highest in the Netherlands and lowest by far in the U.S.. ${ }^{14}$ Based on microdata from the three countries, we calculated and report below an alternative measure of replacement rate.

\footnotetext{
${ }^{13}$ For example, suppose someone worked for 12 years under a plan which promises a benefit equal to 1.5 percent of last earned salary for every year worked. His new plan promises 2.0 percent of last earned salary per year worked. The worker receives credit in his new plan for $12 * 1.5 / 2.0=9$ years of work, as-if those years were worked at the new employer under the new pension plan.

14 There are many ways to calculate replacement rates. Table 4 is therefore not directly comparable to Table 2. However, within table, the rates are computed in the same manner.
} 


\subsection{Private Savings}

In addition to claims on social security and occupational pensions, individuals build up private savings to support them during retirement. Private savings may take many forms. They may be held in financial instruments, in real estate, or other. They are not restricted to after-tax funds. Specifically, we include IRAs, term life insurance, and similar taxsheltered accounts among private savings. The largest differences in private saving across United States, Italy, and the Netherlands lie in opportunities to save in taxsheltered instruments.

Americans may accumulate retirement savings in Individual Retirement Accounts (IRAs). Individuals may contribute up to $\$ 2,000$ annually to IRAs. ${ }^{15}$ In traditional IRAs, contributions are tax-deductible; distributions (including interest) are taxed at the time of the distribution. Contributions are fully tax deductible only for persons whose income falls below certain phase-out levels, which depend on whether the person is covered by an occupational pension. Since 1997, so-called Roth IRAs allow for after-tax contributions; distributions (including interest) are tax-free. By the end of 1999, the assets in IRAs amounted to $\$ 2.47$ trillion (Copeland 2001). By comparison, assets of private DB and DC pension plans amounted to $\$ 2.14$ trillion and $\$ 2.53$ trillion, respectively (Federal Reserve 2001).

There is no Italian equivalent of IRAs. However, all Italians are eligible for term life insurance contracts. The general principle of taxation on these contracts is very favorable: both contributions and benefits are partially tax-exempt. The value of life insurance contracts comprised 5.5 percent of household financial wealth in 1997 (authors' calculations, based on the 1998 SHIW).

The situation is similar in the Netherlands. Dutch law does not recognize IRAs, but offers tax advantages for term life insurance policies. The limit up to which contributions are tax-deferred has fluctuated widely. Prior to 1992 , the limit was $€ 7,300$, fixed in nominal terms. In 1992, the limit was lowered. For the year 2000, it was $€ 5,600$ for a married couple. (Starting in 2001, the limit is lower yet at only $€ 1,000$; it is higher for individuals with income over which no pension rights are accumulated, such as the use of a company car.) Dutch term life insurance payments must take the form of a lifelong or fixed-term annuity. The annuity benefits are subject to income tax.

Rates of return in the stock market have varied substantially across the three countries. Consider the Morgan Stanley Capital International (MSCI) index, representative of large companies and computed consistently over time and across countries. Between 1970 and mid-2001, the overall annual rate of return, including re-invested dividends, was highest in the Netherlands (13.8 percent nominal, 10.9 percent real), followed by the United States (11.9 percent nominal, 8.3 percent real) and Italy (11.2 percent nominal, 2.3

\footnotetext{
${ }^{15}$ Individuals who separate from a job with a pension plan may often take a lump sum distribution of their pension rights. Such distributions may be rolled over into an IRA and remain tax-sheltered. There is no limit on the amount that may be contributed to IRAs in this manner.
} 
percent real). The Italian market exhibited markedly more volatility. For example, the standard deviation of annual nominal returns in Italy was 34.4 percent, compared to 16.6 percent in the U.S. and 21.7 percent in the Netherlands.

\subsection{Capital Market Imperfections}

Access to capital markets for households varies across the three countries. We discuss housing transactions and mortgages and transaction costs of stock purchases.

Transaction costs of housing in the United States consist largely of real estate agent fees (approximately 6 percent of the house price) and legal fees (roughly 2 percent). Transfer taxes are negligible in most areas. In the Netherlands, transaction costs are largely real estate agent fees (typically 1.5 percent of the house price) and transfer tax of 6 percent. Legal fees are minimal by comparison. House transaction costs are higher in Italy than in the United States and the Netherlands. Real estate agent fees are 8-10 percent and a transfer tax of 6-7 percent applies.

There is a well-developed mortgage market in the United States, including a standardized secondary market. Buyers may choose variable or fixed interest rate loans of up to 30 years' maturity. The typical down payment is 10 or 20 percent of the value of the house, but full financing is available. Interest payments are generally fully deductible for income tax purposes. The mortgage market is much less developed in Italy, perhaps due to banks' limited ability to sell the house in case of default on mortgage payments. Anecdotal evidence suggests that the associated legal proceedings may take as long as 10 years. Banks therefore typically require a down payment of 40-50 percent of the price of the house. In the Netherlands, the mortgage market is well-developed with a wide variety of loan options available. Many mortgage products are tied to life insurances, largely to take maximal advantage of the tax deductibility of mortgage interest. In principle, there are no down payment requirements. To cover the transaction costs of buying a house, mortgages of up to 110 percent of the transaction price are available and common. In 1998, per capita mortgage debt in the United States $(\$ 15,421)$ and the Netherlands $(€ 14,167)$ were almost identical and about ten times as large as in Italy $(€ 1,415)$ (De Nederlandsche Bank 2001; Federal Reserve 2001).

The three countries may also face different transaction costs for the purchase and sale of stocks. An informal Internet search in March 2002 revealed roughly comparable fees for unassisted stock transactions via online brokers. In the United States, E-Trade (us.etrade.com) charges \$14.95-19.95 per transaction and Charles Schwab (www.schwab.com) $\$ 29.95$ for up to 1,000 shares. In the Netherlands, Robeco (www.robecodirect.nl) charges 0.3-0.4 percent of the total transaction, often with a $€ 15$ minimum. In Italy, Twicetrade (www.twicetrade.it) charges $€ 12$ plus the lower of $€ 0.019$ per share and $€ 19$. The differences are not large. However, they reflect current online trades only. Actual average commissions during our analysis period (mid to late 1990s), when online banking was far less developed, are likely much higher. We do not have comparable information on trends in transaction costs. 


\subsection{Exposure to Financial Risks Before and After Retirement}

We now turn to financial risks before and after retirement. Before retirement, the main source of financial risk is earnings uncertainty. Casual observation would suggest that in the U.S., earnings uncertainty is considerably larger than in Italy or the Netherlands. Social insurance programs (unemployment, sickness, disability) in the two European countries are generally more generous than in the U.S., and employment protection laws make it relatively hard to fire employees in Italy and the Netherlands. An interesting piece of direct evidence on earnings uncertainty comes from a common question asked in household surveys in the three countries. The question asks respondents directly for the amount of income uncertainty they face. Guiso, Jappelli and Pistaferri (1999) analyzed the coefficient of variation of income uncertainty for the U.S., the Netherlands, and Italy. They found that income uncertainty across respondents had about the same distribution in Italy and the Netherlands. By contrast, U.S. respondents reported much more income uncertainty than the respondents in the two European countries.

Loss of earnings due to disability is another important financial risk before retirement. In all three countries, workers may count on long-term disability insurance in case of disability. Generally, public disability insurance schemes are more generous in Italy and the Netherlands than in the United States. In many cases, workers are covered by private disability insurance in all three countries.

After retirement, the main source of financial risk is health-related. Americans face greater risks of large out-of-pocket medical expenses than their Dutch and Italian counterparts. In the Netherlands, virtually all elderly are covered by comprehensive health insurance with negligible out-of-pocket expenses. In Italy, the public health system grants essentially free assistance to the entire population in case of illness. However, only in-patient assistance is provided, implying substantial out-of-pocket expenses for the elderly in case of a serious illness that requires little hospital care. In the United States, the elderly may face serious out-of-pocket medical expenses, depending on their insurance coverage. Elderly with low income and financial assets are typically eligible for Medicaid, which offers fairly comprehensive insurance, including for deductibles. The risks are also limited for elderly that are covered by both private health insurance and Medicare, a public health insurance program for the elderly and disabled. However, American elderly who rely only on Medicare face substantial risks of large outof-pocket expenses. Medicare consists of two components. Coverage for Part A is almost universal; it covers in-patient expenses in hospitals and skilled nursing facilities. Most elderly also have supplemental (Part B) coverage, purchased at subsidized rates. Medicare requires co-payments that can be substantial, especially in the case of long hospital stays. 


\section{Data}

Our analysis is based on microdata on individuals age 50 and older from each country. For the United States, we use the Health and Retirement Study (HRS); for Italy, the Survey of Household Income and Wealth (SHIW); and for the Netherlands, the SocioEconomic Panel (SEP). We briefly describe each survey.

For the United States, we use the HRS, including all its cohorts. The HRS is a national longitudinal sample of households with at least one person born in 1931-1941 (51-61 years old at the 1992 baseline) or 1923 or before, i.e., with at least one person aged 70 or over in 1993. The 1998 interview added the 1924-30 and 1942-47 birth cohorts, so that the most recent data cover all individuals over age 50. We use the 1998 data and rely on other waves (1992-2000) where longitudinal information is needed. The principal objective of the HRS is to monitor economic transitions in work, income, wealth, and changes in health status. The first wave of data was collected in 1992 (1993 for the pre1923 birth cohort), with follow-ups fielded at approximately two-year intervals. Blacks, Hispanics, and Florida residents were over sampled at a rate of two to one. The 1998 HRS contained 21,351 respondents: 8,949 men and 12,402 women.

The main wealth data for Italy is the Survey of Household Income and Wealth (SHIW), collected by the Banca d'Italia, Italy's central bank. Its main purpose is to collect detailed data on demographics, household consumption, income, and balance sheets. This survey is representative of the Italian population and has been fielded biannually since 1984. Financial wealth data have only been publicly available since 1989. Beginning in 1989, some but not all of the households were re-interviewed in subsequent panels. The panel component has increased over time - in 1989, 29 percent of the households were re-interviewed and by 1995,45 percent were re-interviewed. The sample size is about 8,500 households. The SHIW contains questions on detailed asset and debt categories.

For the Netherlands, we rely on the SocioEconomic Panel (SEP), a representative panel survey conducted by Statistics Netherlands. The SEP covers about 5,000 households and is representative of the non-institutionalized Dutch population. It contains detailed information about a number of household demographic characteristics and collects data on household income and wealth. The SEP has been collected annually since 1984. It is a panel data set. Since 1987, the SEP contains a wealth module with fairly detailed questions on asset and debt categories. These categories have varied somewhat during the course of the panel. Because of problems collecting the data, no asset and debt information has been collected on the self-employed since 1990. In 1997, the SEP contained 8,904 respondents: 4,385 men and 4,519 women. 


\section{Method and Hypotheses}

The aim of this paper is to exploit institutional variation across countries to shed light on the effect of different policies on the wealth accumulation and portfolio choices of households near or in retirement. Since, at this stage, we are only considering three countries, we have in a sense only three data points to generalize from. Thus, if we were to take a completely a-theoretical approach we would have very few degrees of freedom to establish any empirical regularity with reasonable confidence. We therefore take a different approach. Drawing on our review of the literature and the description of institutional differences across countries we formulate a number of stylized predictions, which are next confronted with the data at hand. The more these predictions are corroborated by the microdata, the more confident we can be that the policies in the different countries help explain the differences in wealth accumulation and portfolio composition that we observe.

An important caveat in our analysis will be that we generally assume that policies are exogenous. Thus, for example, we exclude the possibility that social security benefits are generous because citizens of a country have an innate tendency to save too little for retirement.

We briefly characterize a number of stylized facts that we expect to hold in the microdata across the three countries as a result of their institutional differences and the theoretical framework. We formulate our "predictions" as rather informal hypotheses, with generally a ceteris paribus clause to account for other counteracting institutional effects.

\section{Hypothesis 1: The displacement effects of retirement benefits}

A straightforward implication of the $\mathrm{LCH}$ is that more generous retirement benefits will induce less saving for retirement. We will therefore consider replacement rates at retirement in the three countries and predict that the country with the lowest replacement rate will be the country with the highest saving rate, ceteris paribus. Based on the discussion in Sections 3.1 and 0 we expect retirement savings to be most prominent in the U.S. and least prominent in the Netherlands, at least at the median.

\section{Hypothesis 2: The effect of earnings and consumption uncertainty}

Saving for precautionary reasons should be most prominent in a country with the highest earnings uncertainty. We will invoke subjective information on earnings uncertainty to support the assumption that earnings uncertainty is highest in the U.S. and hence that we would expect to have the highest level of precautionary saving in the U.S., again under ceteris paribus conditions. In addition to earnings uncertainty, consumption uncertainty may be important as well. A prime example of consumption uncertainty would be the possibility of unforeseen large out-of-pocket medical expenses. It appears that this kind of consumption risk is considerably larger in the U.S. than in Europe. Hence, even after retirement, when earnings uncertainty presumably does not play a role anymore, we 
would still expect precautionary motives to lead to a stronger desire to hold bequeathable wealth in the U.S. than in Italy or the Netherlands.

\section{Hypothesis 3: The role of capital market imperfections}

In the basic, stripped down, version of the $\mathrm{LCH}$, consumers may be borrowing to finance consumption at young age and enter middle age with negative wealth. Only after earnings exceed optimal lifetime consumption, will saving become positive. Clearly such a pattern will not be observed if capital market imperfections prevent substantial borrowing at young ages. A point in case is the possibility to obtain home mortgages. As observed in Section 3.4, the typical minimum down payment requirement in the U.S. is 10-20 percent. In Italy the minimum down payment is on the order of 40-50 percent. In the Netherlands one can buy a house with a negative down payment up to 10 percent (i.e., one can borrow 110 percent of the market value of the house). Differences in capital market structure in the three countries thus predict that Italy should have the highest saving rate and the Netherlands the lowest. In addition, when considering net household wealth, Italy should be the country where net wealth, as a percentage of gross wealth, is highest.

\section{Hypothesis 4: Portfolio composition}

The preceding hypotheses imply higher levels of private wealth in Italy and the U.S. upon retirement than in the Netherlands. Our review of the literature then suggests that stock ownership in Italy and the U.S. should be higher than in the Netherlands. On the other hand, the less well-developed capital market in Italy may reduce stock ownership in Italy. Similarly, the existence of more earnings and consumption uncertainty (e.g., medical expenses) in the U.S. may depress stock ownership in favor of more secure assets. We hypothesize that stock ownership in the Netherlands will be the lowest among the three countries, because of the lowest level of private wealth. In the U.S., the combination of a well-developed capital market and a high level of private wealth for retirement and precautionary purposes should induce a relatively high level of stock ownership.

\section{Empirical Analysis}

We begin by presenting a number of relevant descriptive statistics for the three countries. We then discuss the evidence in favor of (or against) the hypotheses we have formulated above. Most of the analyses are in simple tabular form, with sometimes an excursion to multivariate analyses.

\subsection{Descriptive Statistics}

For Italy and the Netherlands, we restrict our analysis to households with a head over age 50. For the United States, we consider the entire 1998 HRS, representative of the population age 51 and older. Table 5 presents data for 1998 for the United States and Italy and 1997 for The Netherlands. The table indicates that the age distributions in the three countries are very similar, with samples roughly equally split between heads of 
household under and over age 65. Italian and Dutch respondents are somewhat more likely to be married than American respondents. Based on the educational distributions reported in Table 5, U.S. respondents appear to be somewhat better educated than their Italian and Dutch counterparts. The comparison should be interpreted with caution, though, because the schooling systems differ greatly across the three countries.

Table 5. Demographics and Income (Unit of observation: Household)

\begin{tabular}{|c|c|c|c|}
\hline & U.S. & Italy & Netherlands \\
\hline Number of households & 14,147 & 4,20 & 1,487 \\
\hline \multicolumn{4}{|l|}{ Age household head } \\
\hline $50-59$ & 35.1 & 38.0 & 33.0 \\
\hline $60-64$ & 13.7 & 16.8 & 15.4 \\
\hline $65+$ & 51.2 & 45.2 & 51.6 \\
\hline \multicolumn{4}{|l|}{ Household Structure } \\
\hline Couple & 53.4 & 67.4 & 60.8 \\
\hline Single male & 11.1 & 8.8 & 10.6 \\
\hline Single female & 35.5 & 23.8 & 28.7 \\
\hline \multicolumn{4}{|l|}{ Education household head } \\
\hline Elementary & $33.0^{\mathrm{a}}$ & 51.8 & 30.6 \\
\hline Some high school & & 24.8 & $18.4^{b}$ \\
\hline High school & 29.2 & 16.5 & $32.2^{\mathrm{c}}$ \\
\hline Some college & 37.8 & 7.0 & $18.8^{\mathrm{d}}$ \\
\hline \multicolumn{4}{|l|}{ HH non-capital income } \\
\hline Mean & $\$ 26,500$ & $€ 24,000$ & $€ 24,600$ \\
\hline Median & $\$ 18,800$ & $€ 20,400$ & $€ 21,300$ \\
\hline
\end{tabular}

Note: Definitions of education categories vary:

${ }^{\mathrm{a}}$ less than high school; $\quad{ }^{\mathrm{c}}$ middle vocational;

${ }^{\mathrm{b}}$ lower vocational/junior high school; $\quad{ }^{\mathrm{d}}$ at least high school

The mean non-capital after-tax household income in the U.S. was higher than in Italy and the Netherlands, whereas median income was lower. ${ }^{16}$ The pattern reversal reflects a more equal income distribution in Italy and the Netherlands compared to the United States.

Our hypotheses are couched in terms of accumulated savings and allocation into risky assets. Given the information in the microdata, we define risky assets as stock and bond holdings. An intuitive measure of risky asset allocation is the ratio of risky assets to net worth. Unfortunately, non-negligible subsamples report zero or negative net worth, so that the ratio of risky assets to net worth cannot be determined or is very difficult to

\footnotetext{
${ }^{16}$ The American HRS collects gross income data, whereas the Italian SHIW and Dutch SEP ask for aftertax income. We estimated tax liabilities to convert the American income data to be net of taxes. Since the state of residence and many financial details are unknown, we assume standard deductions and account for federal taxation only. This includes federal income tax and Federal Insurance Contributions Act (FICA) liabilities. Incomes after state income tax, where applicable, are therefore slightly lower than reported in Table 5 .
} 
interpret. Instead, we define two related measures. Consider households' balance sheets in Figure 2.

\begin{tabular}{|c|c|}
\hline Assets & Liabilities \\
\hline Safe (cash, savings accounts) ......... S & Net worth .................. \\
\hline Risky (stocks, bonds) ..................... & Debts ........................ \\
\hline $\begin{array}{l}\text { Gross housing ................................ H } \\
\quad \text { (housing equity + mortgage debt) }\end{array}$ & (mortgage and other) \\
\hline 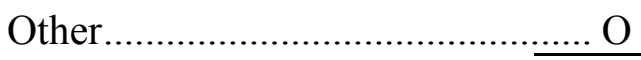 & \\
\hline 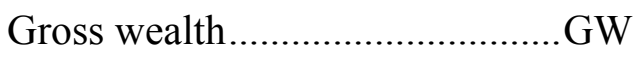 & Gross wealth...................GW \\
\hline
\end{tabular}

Figure 2. Stylized Household Balance Sheet

We decompose the ratio of risky assets to net worth as follows:

$$
\frac{R}{N W}=\frac{R}{G W} \cdot \frac{G W}{N W}=\frac{R}{G W} / \frac{N W}{G W}=\text { Exposure/Solvency }
$$

Very few respondents report having no gross wealth at all. Both "exposure," defined as the ratio of risky assets to gross wealth, and "solvency," defined as the ratio of net worth to gross wealth, are therefore straightforward to construct.

Table 6 characterizes the size and composition of bequeathable household wealth in the three samples. The American and Italian figures are based on 1998 HRS and SHIW, the Dutch on the 1997 SEP. As predicted, the Netherlands has by far the lowest level of private household wealth, both in the mean and in the median. Partly this reflects the lower home ownership rate in the Netherlands for these older cohorts. Stock or bond ownership is highest in the U.S. (33 percent) and lowest in the Netherlands (19 percent). Following Figure 2, we aggregated assets in four broad categories: (1) Safe assets (saving and checking accounts, cash); (2) risky assets (stocks and bonds); (3) housing and other real estate; (4) other. Since the Dutch sample excludes self-employed, we have excluded business equity in all countries. U.S. households clearly hold the most risky assets, both in absolute value and as a fraction of gross wealth. Dutch households hold more of their gross wealth in safe assets than the Americans and Italians. Again, this partly reflects the lower home ownership rate in the Netherlands for this age group. In both the U.S. and the Netherlands, the share of risky assets increased between 1992 and 1997/8 (not shown). The average solvency ratios are large and negative in the United States and Italy, because the ratios are dominated by households with negative net worth that is large relative to their reported gross wealth. 
Table 6. Assets and Asset Allocation

(Unit of observation: household)

(Monetary values in $\$$ for the U.S. and in $€$ for Italy and the Netherlands)

\begin{tabular}{|l|l|r|r|r|}
\hline & & \multicolumn{1}{|c|}{ U.S. } & \multicolumn{1}{|c|}{ Italy } & Netherlands \\
\hline Gross wealth & mean & 276,200 & 168,100 & 95,300 \\
Net worth & median & 130,000 & 96,500 & 45,200 \\
& mean & 253,400 & 166,200 & 79,300 \\
Owns house (\%) & median & 105,000 & 95,000 & 33,500 \\
& mean & 76.8 & 71.8 & 46.5 \\
Owns stocks/bonds (\%) & median & 100 & 100 & 0 \\
& mean & 33.0 & 26.8 & 18.7 \\
Exposure (R/GW) & median & 0 & 0 & 0 \\
& mean & 0.079 & 0.051 & 0.039 \\
Solvency (NW/GW) & median & 0 & 0 & 0 \\
& mean & -51.8 & -18.3 & 0.62 \\
Housing equity (if owner) & median & 1 & 1 & 1 \\
& mean & 128,200 & 121,800 & 111,600 \\
Stocks/bonds (if owner) & median & 95,000 & 100,000 & 95,800 \\
& mean & 169,500 & 54,483 & 45,700 \\
Portfolio shares (\%) & median & 45,000 & 20,000 & 16,900 \\
Safe (S/GW) & & & & \\
Risky (R/GW) & mean & 20.4 & 29.4 & 43.4 \\
House (H/GW) & mean & 7.9 & 5.1 & 3.9 \\
Other (O/GW) & mean & 45.6 & 53.2 & 38.6 \\
& mea & 26.0 & 12.3 & 14.0 \\
\hline
\end{tabular}

\subsection{Empirical Evidence for the Hypotheses}

\section{Hypothesis 1: The displacement effects of retirement benefits}

Although we have provided some evidence that replacement rates at retirement are lowest in the U.S. and highest in the Netherlands, it is useful to exploit our microdata to shed further light on this. The replacement rates given in Section 3.2 above were based on hypothetical (median) individuals in the three different countries, and on "plausible" institutional parameters. Here we take a different approach. We exploit the longitudinal nature of the data to consider incomes in the waves before and after a respondent first reports being retired to gauge the actual change in income experienced by those who retire. For example, if someone first reports being retired in 1994, we consider incomes as reported in 1993 and 1995. (In the American HRS and Italian SHIW data, the waves are two years apart, except three years for the 1995-8 SHIW.) This approach avoids contamination from part-year employment. We consider household non-capital income before and after individual retirement. This assumes resource sharing within a household, so that for instance a transfer of resources by other household members compensates for a drop in the new retiree's income. This assumption acknowledges the 
joint nature of retirement decisions (e.g., Zweimüller and Winter-Ebmer, 1996; Gustman and Steinmeier, 1994; Maestas, 2001). Finally, we consider after-tax income, ${ }^{17}$ expressed in constant 1998 dollars.

The top panel of Table 7 presents empirical after-tax replacement rates for the United States based on the 1992-2000 HRS. The table compares incomes in the wave before retirement and the wave after retirement, ${ }^{18}$ i.e., at $\mathrm{t}-2$ and $\mathrm{t}+2$. Post-retirement income is substantially lower than pre-retirement income, both in the mean and the median. ${ }^{19}$ The average replacement rate is well above unity, but this is driven by a small number of respondents with particularly low pre-retirement income. The median replacement rate is 75.7 percent. There is large variation: at the $10^{\text {th }}$ percentile, income dropped by threequarters after retirement, whereas it increased by three-quarters in real terms at the $90^{\text {th }}$ percentile.

To put these findings in perspective, compare the income changes between the year before retirement and the year after retirement with income changes of individuals who did not retire (i.e., who worked in years $t-2, t, t+2$, or who were retired in all three waves). We observe that the latter individuals also experienced a decline in real income, at least at the median. The decline in income is far smaller at the median ( 2.2 percent) than the median decline among newly retired individuals ( 24.3 percent).

The replacement rate improves if we assume that individuals who retire can annuitize their wealth and consume the annuity. Adding the annuity value of bequeathable wealth to post-retirement income, possible consumption levels exceed pre-retirement income for most households. We define the generalized replacement rate as the sum of postretirement income and annuity value of private wealth divided by pre-retirement income. At the median, the generalized replacement rate is above one (111.4 percent). Even at the $10^{\text {th }}$ percentile, post-retirement consumption may be sustained at almost half the level of pre-retirement income.

The bottom part of Table 7 presents a similar analysis for household net worth around retirement and compares changes to wealth changes of households in which no retirement takes place. Most households experience wealth growth, but wealth grows somewhat faster for households who do not have a recently retired member. At the median, the increase is 2.2 percent among households that transitioned through retirement and 6.6 percent among those who did not.

\footnotetext{
${ }^{17}$ See footnote 16 (page 13 ).

${ }^{18}$ For the United States and Italy, retirement is defined based on respondents' own report of (complete) retirement status. For the Netherlands, retirement is defined as receiving some form of income transfer (pension, disability, or unemployment benefits), being over 50 years old, and not doing any work for pay.

${ }^{19}$ In order to exploit the longitudinal feature of the HRS, the sample consists of original HRS respondents, i.e., those born in 1931-41 and their spouses. The sample is thus younger than the sample used in Table 5, which included all HRS cohorts. This explains why mean and median income levels in Table 7 exceed those in Table 5.
} 
Table 7. Empirical replacement rates, wealth accumulation, and income growth in the United States

\begin{tabular}{|c|c|c|c|c|c|}
\hline & Obs. & Mean & $\begin{array}{c}\text { 10th } \\
\text { Percentile }\end{array}$ & Median & $\begin{array}{c}\text { 90th } \\
\text { Percentile }\end{array}$ \\
\hline \multicolumn{6}{|l|}{ Newly retired } \\
\hline $\begin{array}{l}\text { Pre-retirement HH non- } \\
\text { capital income }\end{array}$ & 1,953 & 36,600 & 6,900 & 30,600 & 69,500 \\
\hline Post-retirement income & 1,797 & 26,100 & 6,500 & 21,200 & 47,300 \\
\hline $\begin{array}{l}\text { Post-retirement income }+ \\
\text { annuity value of wealth }\end{array}$ & 1,797 & 44,100 & 9,000 & 34,100 & 83,100 \\
\hline Replacement rate $(\%)$ & 1,749 & 147.1 & 28.7 & 75.7 & 175.2 \\
\hline Generalized repl. rate $^{a}$ & 1,749 & 261.0 & 47.6 & 111.4 & 271.6 \\
\hline \multicolumn{6}{|l|}{ Not newly retired } \\
\hline Non-capital HH inc. t-2 & 29,442 & 36,800 & 7,000 & 30,000 & 69,200 \\
\hline Non-capital HH inc. $\mathrm{t}+2$ & 28,894 & 35,900 & 6,300 & 29,500 & 68,700 \\
\hline Income ratio $(\mathrm{t}+2) /(\mathrm{t}-2)(\%)$ & 19,463 & 213.1 & 33.5 & 97.8 & 179.6 \\
\hline \multicolumn{6}{|l|}{ Newly retired } \\
\hline Pre-retirement HH net worth & 1,982 & 215,200 & 1,100 & 115,600 & 491,600 \\
\hline Post-retirement HH net worth & 1,815 & 254,900 & 1,000 & 124,700 & 594,500 \\
\hline Wealth growth $(\%)$ & 1,746 & 41.9 & -85.1 & 2.2 & 169.0 \\
\hline \multicolumn{6}{|l|}{ Not newly retired } \\
\hline Net worth $\mathrm{t}-2$ & 29,735 & 246,400 & 2,500 & 113,200 & 552,200 \\
\hline Net worth $\mathrm{t}+2$ & 29,204 & 267,700 & 3,200 & 119,900 & 588,000 \\
\hline Wealth growth (\%) & 19,936 & 114.3 & -83.2 & 6.6 & 192.8 \\
\hline
\end{tabular}

${ }^{a}$ Post-retirement non-capital household income + annuity value of wealth divided by pre-retirement noncapital household income. The annuity value assumes a 3 percent interest rate.

Similar to Table 7, Table 8 documents income replacement rates, wealth accumulation, and income growth in Italy, based on 1987-98 data. Table 7 was in 1998 dollars; Table 8 in 1998 euros. As in the United States, real household non-capital income tends to drop after retirement. However, the declines are milder. At the median, post-retirement Italian household incomes replace 85.9 percent of pre-retirement income, about ten percentage points above the median U.S. replacement rate. While there is substantial variation, the differences are smaller than in the U.S. For example, at the $10^{\text {th }}$ and $90^{\text {th }}$ percentile, post-retirement incomes are about 50 percent below and above their preretirement levels, compared to three-quarter differences in the United States. At the median, real incomes among households that did not transition through a retirement remained almost exactly constant. Naturally, the replacement rates increase when including the annuity value of net worth. The median generalized replacement rate for new retirees in Italy is 124.5 percent, again greater than in the United States (111.4 percent).

Italian households enjoyed greater wealth gains than American households during the mid and late 1990s. At the median, net worth among households with a new retiree increased by 24 percent. This gain exceeds the gain among households that did not 
experience a retirement (14.5 percent), probably because of severance payments (see above).

Table 8. Empirical replacement rates, wealth accumulation, and income growth in Italy

\begin{tabular}{|c|c|c|c|c|c|}
\hline & Obs. & Mean & $\begin{array}{c}10 \text { th } \\
\text { Percentile }\end{array}$ & Median & $\begin{array}{c}\text { 90th } \\
\text { Percentile }\end{array}$ \\
\hline \multicolumn{6}{|l|}{ Newly retired } \\
\hline $\begin{array}{l}\text { Pre-retirement HH non- } \\
\text { capital income }\end{array}$ & 402 & 33,800 & 15,300 & 30,150 & 55,300 \\
\hline Post-retirement income & 402 & 30,300 & 11,600 & 26,150 & 51,800 \\
\hline $\begin{array}{l}\text { Post-retirement income }+ \\
\text { annuity value of wealth }\end{array}$ & 402 & 46,100 & 14,000 & 39,100 & 79,500 \\
\hline Replacement rate (\%) & 402 & 97.3 & 49.1 & 85.9 & 147.5 \\
\hline Generalized repl. rate ${ }^{a}$ & 402 & 143.7 & 65.5 & 124.5 & 231.9 \\
\hline \multicolumn{6}{|l|}{ Not newly retired } \\
\hline Non-capital HH inc. t-2 & 5,682 & 25,300 & 9,800 & 21,500 & 45,100 \\
\hline Non-capital $\mathrm{HH}$ inc. $\mathrm{t}+2$ & 5,682 & 26,000 & 9,600 & 21,400 & 46,300 \\
\hline Income ratio $(\mathrm{t}+2) /(\mathrm{t}-2)(\%)$ & 5,673 & 112.0 & 57.9 & 100.8 & 170.0 \\
\hline \multicolumn{6}{|l|}{ Newly retired } \\
\hline Pre-retirement HH net worth & 402 & 187,200 & 7,700 & 122,650 & 435,200 \\
\hline Post-retirement $\mathrm{HH}$ net worth & 402 & 225,000 & 11,100 & 153,650 & 515,400 \\
\hline Wealth growth $(\%)$ & 398 & 320.8 & -68.4 & 24.0 & 350.6 \\
\hline \multicolumn{6}{|l|}{ Not newly retired } \\
\hline Net worth t-2 & 5,682 & 154,600 & 3,800 & 87,900 & 350,600 \\
\hline Net worth $\mathrm{t}+2$ & 5,682 & 189,900 & 4,400 & 110,000 & 431,500 \\
\hline Wealth growth $(\%)$ & 5,595 & 305.2 & -73.3 & 14.5 & 373.2 \\
\hline
\end{tabular}

${ }^{a}$ Post-retirement non-capital household income + annuity value of wealth divided by pre-retirement noncapital household income. The annuity value assumes a 3 percent interest rate.

Table 9 shows the same set of statistics for the Netherlands, based on 1984-97 income reports and 1987-97 wealth data. Income and wealth values are in 1998 euros. Dutch replacement rates generally exceed those of both the United States and Italy. At the median, fully 102.3 percent of real pre-retirement income is replaced. The spread is narrower than in the other two countries. At the $10^{\text {th }}$ and $90^{\text {th }}$ percentile, only about onethird of pre-retirement income is lost or gained, compared to one-half in Italy and threequarters in the United States. Dutch households without a new retiree also fared well-at the median, their real household non-capital income rose by 8.1 percent. The spread is again small, much smaller than in the United States and Italy. (This is in part explained by the fact that the Dutch income and wealth figures refer to survey waves that are only two years apart; the Dutch SEP survey is conducted annually, whereas American HRS and Italian SHIW waves are generally two years apart.) Adding in the annuity value of net worth increases the replacement rates, though not by very much. This reflects the small average wealth holdings among Dutch households. 
In the Netherlands, households with a newly retired member enjoyed an increase of 4.5 percent in net worth, far lower than in Italy but somewhat higher than in the United States. The increase among households without a retiring member was one-eighth in two years time, more than the comparable American and Italian figures.

Table 9. Empirical replacement rates, wealth accumulation, and income growth in the Netherlands

\begin{tabular}{|c|c|c|c|c|c|}
\hline & Obs. & Mean & $\begin{array}{c}\text { 10th } \\
\text { Percentile }\end{array}$ & Median & $\begin{array}{c}\text { 90th } \\
\text { Percentile }\end{array}$ \\
\hline \multicolumn{6}{|l|}{ Newly retired } \\
\hline $\begin{array}{l}\text { Pre-retirement HH non- } \\
\text { capital income }\end{array}$ & 772 & 22,200 & 10,500 & 18,800 & 38,600 \\
\hline Post-retirement income & 772 & 21,900 & 10,900 & 18,600 & 37,400 \\
\hline $\begin{array}{l}\text { Post-retirement income }+ \\
\text { annuity value of wealth }\end{array}$ & 772 & 26,900 & 12,100 & 22,900 & 49,700 \\
\hline Replacement rate $(\%)$ & 772 & 113.9 & 68.0 & 102.3 & 138.3 \\
\hline 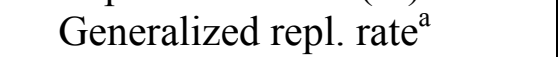 & 772 & 137.1 & 80.8 & 114.5 & 187.2 \\
\hline \multicolumn{6}{|l|}{ Not newly retired } \\
\hline Non-capital HH inc. t-1 & 52,333 & 27,300 & 12,600 & 25,900 & 43,200 \\
\hline Non-capital HH inc. $\mathrm{t}+1$ & 52,333 & 29,600 & 13,000 & 28,100 & 47,000 \\
\hline Income ratio $(\mathrm{t}+1) /(\mathrm{t}-1)(\%)$ & 52,333 & 124.3 & 81.8 & 108.1 & 138.9 \\
\hline \multicolumn{6}{|l|}{ Newly retired } \\
\hline Pre-retirement $\mathrm{HH}$ net worth & 802 & 63,400 & 600 & 23,400 & 172,600 \\
\hline Post-retirement $\mathrm{HH}$ net worth & 802 & 67,000 & 800 & 23,000 & 175,400 \\
\hline Wealth growth $(\%)$ & 800 & -82.0 & -61.2 & 4.5 & 128.3 \\
\hline \multicolumn{6}{|l|}{ Not newly retired } \\
\hline Net worth t-1 & 55,995 & 47,900 & 100 & 23,300 & 121,500 \\
\hline Net worth $\mathrm{t}+1$ & 55,995 & 57,100 & 400 & 31,100 & 141,100 \\
\hline Wealth growth $(\%)$ & 55,995 & 118.2 & -79.7 & 12.5 & 164.2 \\
\hline
\end{tabular}

${ }^{a}$ Post-retirement non-capital household income + annuity value of wealth divided by pre-retirement noncapital household income. The annuity value assumes a 3 percent interest rate.

In summary, replacement rates are lowest in the United States and highest in the Netherlands, with a gap at the median of 26.6 percentage points. However, American households accumulate far more private savings than their Dutch counterparts. The replacement rate gap narrows to just 3.1 percentage points when we include the annuity value of net worth in the calculations. This is fully consistent with a life cycle model in which retirement saving is crowded out by institutional old age pension provisions in the Netherlands, but much less so in the U.S.

\section{Hypothesis 2: The effect of earnings and consumption uncertainty}

Section 3.5 argued that Americans face greater financial risks, both before and after retirement. A problem in a cross-country context with the data at hand is that we do not have individual information on the amount of uncertainty faced by the individuals in our 
sample. Since there are at least two different strong incentives for households in the U.S. to accumulate more private wealth than in Italy or the Netherlands (precaution and to provide for retirement), it is probably impossible to disentangle the relative influence of the two different incentives. We have argued above that in any case retirement provisions provide a powerful explanation for the difference in wealth accumulation between the U.S. and the Netherlands. Providing further insight into the patterns of wealth accumulation in Italy, the Netherlands, and the U.S., Table 10 presents results of a regression of household net worth on a number of household characteristics.

Since both household income and net worth have a skewed distribution, we have applied a log-like transformation to these variables. A direct logarithmic transformation is not possible, since both variables can take on negative values. Hence we adopted the inverse hyperbolic sine: $h(x)=\log \left(\sqrt{x^{2}+1}+x\right)$. For values of $x$ not too close to zero, $h(x)$ is approximately equal to $\log (2 x)$ for positive $x$ and $-\log (2 x)$ for negative $x$. The function $h(x)$ is anti-symmetric: $h(x)=-h(-x)$. The drawback of the inverse hyperbolic sine in comparison to the logarithm is that it is not invariant to a change of units. The regressions reported involve both quantities measured in U.S. dollars and quantities measured in euros. If we were to use logs of the monetary variables, the currency differences would simply be absorbed in the country-specific intercepts. For the inverse hyperbolic sine, that is only approximately true. ${ }^{20}$

Table 10 presents two regressions. The first regression involves full interactions of all variables with country dummies, which is equivalent with having separate equations for each country. It turned out that the age functions of Italy and the Netherlands are quite similar, an impression that was confirmed by a statistical test. Hence, the regression was repeated with identical age functions for the Netherlands and Italy. We specified the effect of age on wealth accumulation as a fifth degree polynomial. Rather than presenting the estimated coefficients of the polynomials, we sketch the estimated age functions in Figure 3.
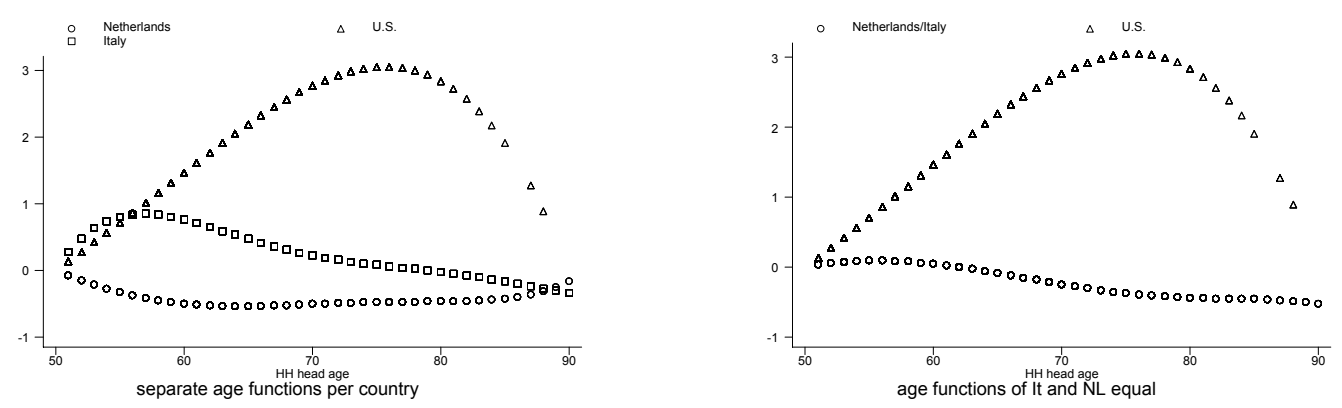

Figure 3. Estimated age functions in the net worth regressions

\footnotetext{
${ }^{20}$ We measure net worth in dollars and euros, so that the outcome is far from zero for most respondents with nonzero net worth. At zero, there is no scale issue.
} 
Table 10. Cross country regressions for net worth

\begin{tabular}{|c|c|c|}
\hline \multicolumn{3}{|c|}{$\begin{array}{l}\text { Dependent variables: } \\
\text { Inverse hyperbolic sine } \mathrm{h}(.) \text { of household net worth }\end{array}$} \\
\hline & $\begin{array}{c}\text { Separate age } \\
\text { functions }\end{array}$ & $\begin{array}{l}\text { IT/NL same } \\
\text { age function }\end{array}$ \\
\hline Dummy SEP1992 & $\begin{array}{r}541.482 \\
(0.74)\end{array}$ & $\begin{array}{c}4.479 \\
(6.26) * *\end{array}$ \\
\hline Dummy SEP1997 & $\begin{array}{c}541.655 \\
(0.74)\end{array}$ & $\begin{array}{l}4.673 \\
(6.49)^{* *}\end{array}$ \\
\hline Dummy HRS1992 & $\begin{array}{r}622.872 \\
(0.86)\end{array}$ & $\begin{array}{c}-41.788 \\
(0.56)\end{array}$ \\
\hline Dummy HRS1998 & $\begin{array}{c}622.080 \\
(0.85)\end{array}$ & $\begin{array}{r}-42.579 \\
(0.57)\end{array}$ \\
\hline $\mathrm{h}$ (non-cap hh inc.) US & $\begin{array}{c}0.308 \\
(17.61)^{* *}\end{array}$ & $\begin{array}{c}0.308 \\
(17.61)^{* *}\end{array}$ \\
\hline$h$ (non-cap hh inc.) IT & $\begin{array}{c}0.668 \\
(11.80)^{* *}\end{array}$ & $\begin{array}{c}0.668 \\
(11.81)^{* *}\end{array}$ \\
\hline$h$ (non-cap hh inc.) NL & $\begin{array}{r}0.031 \\
(0.72)\end{array}$ & $\begin{array}{c}0.024 \\
(0.56)\end{array}$ \\
\hline Dummy retired, US & $\begin{array}{c}-0.697 \\
(11.52)^{* *}\end{array}$ & $\begin{array}{c}-0.697 \\
(11.52)^{* *}\end{array}$ \\
\hline Dummy retired, IT & $\begin{array}{c}0.907 \\
(5.21)^{* *}\end{array}$ & $\begin{array}{c}0.933 \\
(5.57)^{* *}\end{array}$ \\
\hline Dummy retired, NL & $\begin{array}{c}0.530 \\
(2.05)^{*}\end{array}$ & $\begin{array}{l}0.648 \\
(3.15)^{* *}\end{array}$ \\
\hline High school, US & $\begin{array}{l}1.073 \\
(8.68)^{* *}\end{array}$ & $\begin{array}{l}1.073 \\
(8.68)^{* *}\end{array}$ \\
\hline More than H.S., US & $\begin{array}{c}1.682 \\
(18.07)^{* *}\end{array}$ & $\begin{array}{c}1.682 \\
(18.06)^{* *}\end{array}$ \\
\hline Some high school, IT & $\begin{array}{c}0.900 \\
(4.73)^{* *}\end{array}$ & $\begin{array}{c}0.916 \\
(4.86)^{* *}\end{array}$ \\
\hline High school, IT & $\begin{array}{l}1.529 \\
(6.89)^{* *}\end{array}$ & $\begin{array}{l}1.550 \\
(7.03)^{* *}\end{array}$ \\
\hline Some college, IT & $\begin{array}{l}2.016 \\
(6.47)^{* *}\end{array}$ & $\begin{array}{l}2.017 \\
(6.48)^{* *}\end{array}$ \\
\hline Lower voc./jr. high, NL & $\begin{array}{c}1.034 \\
(4.02)^{* *}\end{array}$ & $\begin{array}{l}1.009 \\
(3.94)^{* *}\end{array}$ \\
\hline Middle vocational, NL & $\begin{array}{c}2.044 \\
(8.92)^{* *}\end{array}$ & $\begin{array}{l}1.989 \\
(8.82)^{* *}\end{array}$ \\
\hline Some college, NL & $\begin{array}{c}2.829 \\
(10.42)^{* *}\end{array}$ & $\begin{array}{c}2.788 \\
(10.41)^{* *}\end{array}$ \\
\hline Observations & 21,517 & 21,517 \\
\hline R-squared & 0.08 & 0.08 \\
\hline
\end{tabular}

Absolute value of $\mathrm{t}$ statistics in parentheses;

Significance: $*=5 \% ; * *=1 \%$ 
Figure 3 shows that after age 50, American households keep accumulating wealth at a brisk pace, whereas the age profile in the Netherlands and Italy is approximately flat or slightly downward sloping. This would be consistent with the prevalence of a precautionary motive to guard against high out-of-pocket medical costs in the U.S. as compared to Italy and the Netherlands. Here, and repeatedly in subsequent analyses below, we have to offer the caveat that we are not controlling for cohort effects, so that the age effects we observe may be (and probably are) contaminated by cohort effects. Disentangling age and cohort effects is beyond the scope of the current study.

Since the definitions of education levels differ substantially across the three countries, all education dummies are country-specific. The lowest education category is always the reference category. Net worth increases monotonically with education in all three countries.

The effect of being retired differs substantially across the three countries, with a negative effect in the U.S. and positive effects in the Netherlands and Italy. We should be somewhat careful in interpreting these results, as retirement status is correlated with age. In particular, the negative effect of being retired on net worth in the U.S should be considered jointly with the strong positive age effect on net worth, shown in Figure 3. More importantly, retirement may be partly endogenous in the sense that retirement is more likely for individuals with more wealth. Thus the positive sign of the retirement dummy in Italy and the Netherlands may simply reflect that people with more wealth are more likely to retire. With this interpretation, the sign of the retirement dummy in the U.S. is harder to understand.

Household income has a positive influence on capital accumulation. However, the strength of the effect varies substantially across the three countries. In the Netherlands the effect of income is very small and not statistically significant. In Italy and the U.S. it is much bigger and very significant. The discussion of the next hypothesis interprets this pattern.

\section{Hypothesis 3: The role of capital market imperfections}

The implications of the differences in capital markets in the U.S., the Netherlands, and Italy are that ceteris paribus, Italy should have the highest saving rate and the Netherlands the lowest (Section 6). In addition, when considering net household wealth Italy should be the country where net wealth, as a percentage of gross wealth, should be highest. The former implication is hard to test directly, because of other factors influencing saving rates, but the latter implication is easy to verify.

Table 6 shows that median solvency (net worth divided by gross wealth) is equal to one in all three countries. The ratios of median net worth and median gross wealth in Table 6 are 0.81 in the U.S., 0.98 in Italy, and 0.74 in the Netherlands. Thus, for a given level of net worth Italian households borrow considerably less money than households in the U.S. and the Netherlands. The weaker borrowing constraints in the latter countries induce lower private capital accumulation. 
Somewhat tentatively, we interpret the high coefficient of non-capital income in the wealth regressions in Table 10 for Italy as another indication of the relevance of borrowing constraints. Conceivably, the harder it is to borrow money to invest in profitable undertakings (e.g., real estate or stocks), the more important income becomes as a source of capital for investment. Thus ceteris paribus the connection between income and wealth accumulation would be stronger in Italy than in the U.S. or the Netherlands.

\section{Hypothesis 4: Portfolio composition}

In Section 5, we hypothesized that stock ownership in the Netherlands will be the lowest among the three countries, because of the lowest level of private wealth. In the U.S., the combination of a well-developed capital market and a high level of private wealth for retirement purposes should induce a relatively high level of stock ownership. Italy should be in between, because it has a relatively high level of private wealth but a lessdeveloped capital market. To shed light on the plausibility of these hypotheses, Table 11 presents results from cross-country regressions of the share of risky assets (stocks and bonds) in gross wealth. The approach is similar to the approach in Table 10. We start with separate analyses by country and then simplify the model by imposing equality of parameters allowed by the data. Since shares are between zero and one by construction, we use a two-limit Tobit model to estimate the equation, with a lower limit equal to zero and an upper limit equal to one.

The first column presents estimates of the unrestricted equations. A test for equality of the age functions across countries is far from rejection and hence the second column imposes equal age functions. A test of equality of the income coefficients across the three countries is almost rejected at the 5 percent level $(F(2,21419)=2.83, p=.0590)$. Similarly, we cannot reject the hypothesis that the net worth coefficients of the U.S. and Italy are equal $(\mathrm{F}(1,21419)=2.73, \mathrm{p}=.0984)$ at the 5 percent level. The last column presents estimation results with these equalities imposed. Figure 4 sketches the estimated age function, which turns out to be fairly flat in the age range where most of the data points are.

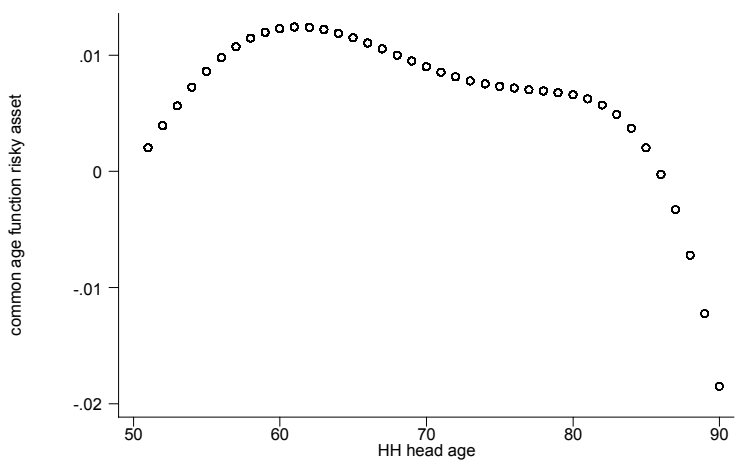

Figure 4. A common age function to explain risky asset share across the three countries 
Table 11. The share of risky assets across countries

\begin{tabular}{|c|c|c|c|}
\hline \multicolumn{4}{|c|}{ Dependent variables: share of risky assets in gross wealth } \\
\hline & $(1)$ & (2) & (3) \\
\hline Dummy HRS1992 & -43.591 & $\begin{array}{c}0.205 \\
(045) *\end{array}$ & $\begin{array}{c}0.062 \\
(419) * *\end{array}$ \\
\hline Dummy HRS1998 & -43.554 & 0.244 & 0.101 \\
\hline Dummy SEP1992 & $\begin{array}{r}-29.098 \\
(0.42)\end{array}$ & $\begin{array}{l}-0.437 \\
(3.60)^{* *}\end{array}$ & $\begin{array}{l}-0.643 \\
(7.54)^{* *}\end{array}$ \\
\hline Dummy SEP1997 & $\begin{array}{r}-29.077 \\
(0.42)\end{array}$ & $\begin{array}{l}-0.415 \\
(3.39)^{* *}\end{array}$ & $\begin{array}{l}-0.631 \\
(7.28) * *\end{array}$ \\
\hline $\mathrm{h}$ (non-cap inc.) US & $\begin{array}{c}0.015 \\
(9.17)^{* *}\end{array}$ & $\begin{array}{c}0.015 \\
(9.24)^{* *}\end{array}$ & \\
\hline h(non-cap inc.) IT & $\begin{array}{l}0.018 \\
(2.83)^{* *}\end{array}$ & $\begin{array}{c}0.019 \\
(2.91)^{* *}\end{array}$ & \\
\hline h(non-cap inc.) NL & $\begin{array}{c}0.004 \\
(1.00)\end{array}$ & $\begin{array}{c}0.004 \\
(0.96)\end{array}$ & \\
\hline $\mathrm{h}$ (net worth) US & $\begin{array}{c}0.052 \\
(32.30)^{* *}\end{array}$ & $\begin{array}{c}0.052 \\
(32.36)^{* *}\end{array}$ & \\
\hline h(net worth) IT & $\begin{array}{c}0.060 \\
(12.01)^{* *}\end{array}$ & $\begin{array}{c}0.061 \\
(12.14)^{* *}\end{array}$ & \\
\hline h(net worth) NL & $\begin{array}{c}0.109 \\
(15.32)^{* *}\end{array}$ & $\begin{array}{c}0.109 \\
(15.30)^{* *}\end{array}$ & $\begin{array}{c}0.105 \\
(14.67)^{* *}\end{array}$ \\
\hline Dummy retired, US & $\begin{array}{l}-0.000 \\
(0.00)\end{array}$ & $\begin{array}{c}0.001 \\
(0.17)\end{array}$ & $\begin{array}{r}0.001 \\
(0.17)\end{array}$ \\
\hline Dummy retired, IT & $\begin{array}{c}0.075 \\
(4.89)^{* *}\end{array}$ & $\begin{array}{c}0.067 \\
(4.87)^{* *}\end{array}$ & $\begin{array}{c}0.068 \\
(4.95)^{* *}\end{array}$ \\
\hline Dummy retired, NL & $\begin{array}{r}0.031 \\
(1.10)\end{array}$ & $\begin{array}{c}0.047 \\
(2.39)^{*}\end{array}$ & $\begin{array}{c}0.050 \\
(2.50)^{*}\end{array}$ \\
\hline High school, US & $\begin{array}{l}-0.005 \\
(0.43)\end{array}$ & $\begin{array}{l}-0.006 \\
(0.52)\end{array}$ & $\begin{array}{l}-0.006 \\
(0.54)\end{array}$ \\
\hline More than H.S., US & $\begin{array}{c}0.075 \\
(9.45)^{* *}\end{array}$ & $\begin{array}{c}0.074 \\
(9.34)^{* *}\end{array}$ & $\begin{array}{c}0.074 \\
(9.29)^{* *}\end{array}$ \\
\hline Some H.S., IT & $\begin{array}{c}0.085 \\
(5.14)^{* *}\end{array}$ & $\begin{array}{c}0.089 \\
(5.49)^{* *}\end{array}$ & $\begin{array}{c}0.093 \\
(5.80)^{* *}\end{array}$ \\
\hline High school, IT & $\begin{array}{c}0.143 \\
(7.83)^{* *}\end{array}$ & $\begin{array}{c}0.146 \\
(8.09)^{* *}\end{array}$ & $\begin{array}{c}0.155 \\
(8.91)^{* *}\end{array}$ \\
\hline Some college, IT & $\begin{array}{c}0.154 \\
(6.31)^{* *}\end{array}$ & $\begin{array}{c}0.156 \\
(6.38)^{* *}\end{array}$ & $\begin{array}{c}0.169 \\
(7.35)^{* *}\end{array}$ \\
\hline L.voc./j.high, NL & $\begin{array}{l}-0.011 \\
(0.33)\end{array}$ & $\begin{array}{l}-0.015 \\
(0.46)\end{array}$ & $\begin{array}{c}0.003 \\
(0.10)\end{array}$ \\
\hline Middle voc., NL & $\begin{array}{c}0.088 \\
(3.38)^{* *}\end{array}$ & $\begin{array}{c}0.084 \\
(3.22)^{* *}\end{array}$ & $\begin{array}{c}0.094 \\
(3.55)^{* *}\end{array}$ \\
\hline $\begin{array}{l}\text { Some college, NL } \\
\text { h(non-cap income) } \\
\text { h(net worth) }\end{array}$ & $\begin{array}{c}0.170 \\
(6.09)^{* *}\end{array}$ & $\begin{array}{c}0.169 \\
(6.10)^{* *}\end{array}$ & $\begin{array}{c}0.182 \\
(6.49)^{* *} \\
0.015 \\
(9.67)^{* *} \\
0.053 \\
(34.39)^{* *}\end{array}$ \\
\hline Observations & 21447 & 21445 & 21344 \\
\hline Pseudo R-squared & .21 & .21 & .21 \\
\hline
\end{tabular}


For convenience, we restrict a discussion of Table 11 to the last column. Household income has a relatively small but significant direct influence on the share of risky assets held. Its influence is positive, which would be consistent with a model where income can be used to buffer risks incurred by investing in the risky assets (i.e., having a higher noncapital income reduces background risk in some informal sense). Of course, there is also an indirect effect of income via its effect on total net worth, as discussed with respect to Table 10 above. Net worth has a positive effect on the share of risky assets in all three countries, as expected.

The share of risky assets in gross wealth increases with education in all countries (except the difference between high school and less than high school in the U.S.; the difference between these two education levels is not statistically significant). This can be interpreted in at least two different ways: (1) owning stocks or bonds requires a certain level of knowledge which is more likely to be present among the higher-educated; (2) a higher education level reduces risks in the labor market and this reduction in background risk makes an individual less risk-averse.

We note that the indicator for being retired is insignificant in the U.S and significantly positive in both Italy and the Netherlands. A possible interpretation is that after retirement income and consumption risks have essentially disappeared in Italy and the Netherlands, whereas in the U.S. consumption risk associated with adverse health shocks becomes more important. This risk reduction after retirement in Italy and the Netherlands would allow households to take on more risk in the stock market.

It is tempting to interpret the country- and wave-specific dummies as propensities to hold risky assets after controlling for the variables listed in Table 11. One should note however, that in general the values of the dummies are sensitive to the scaling of the monetary variables. If for instance, we switch from dollars and euros to thousands of dollars and euros, then to a good approximation all monetary variables are reduced by $\ln (1,000)=6.91$. Since the monetary variables have different coefficients for different countries such changes in monetary units affect country- and wave-specific dummies differentially, without changing the underlying model. The only valid comparison in Table 11 is between Italy and the U.S. in the last column, because we have restricted the coefficients of net worth and household income to be equal. We notice that the dummies for the U.S. are significantly positive, consistent with the notion that a more developed capital market in the U.S. facilitates stock and bond ownership, controlling for education, wealth, and demographics. 


\section{Conclusion}

The analysis in this paper is a first attempt at consistently exploiting institutional variation across countries to improve our understanding of wealth accumulation and portfolio choice of households at or near retirement. The number of countries considered is limited, as is the amount of detail in the data that we have been able to use. The stylized facts that we are able to glean from the microdata are certainly consistent with the hypotheses that we formulated. In summary, their main implications are as follows:

- Americans should save more for retirement than the Dutch or the Italians;

- Americans should save more due to more exposure to uninsurable income and consumption risk;

- Italians should save more due to severe borrowing constraints in their country;

- The Dutch should have relatively low stockholdings due to the low level of private wealth;

- Stock-ownership in the U.S. should be higher than in Italy because of more developed capital markets in the United States.

While each of these implications is borne out by the data, it is in general not possible to establish the relative magnitude of factors influencing wealth accumulation or portfolio choice. For instance, both low replacement rates at retirement and higher consumption and income risk in the U.S. imply that Americans should save more than Europeans. Without further analysis, we cannot determine what the relative role of these factors is.

It is worthwhile to extend the analysis in two main directions. First, it is very desirable to add countries to have more institutional variation that can be exploited. Second, the current data can be analyzed more extensively and more information can be brought to bear on the hypotheses formulated. In particular, one could exploit the longitudinal nature of the data more, e.g., to disentangle age and cohort effects but also to exploit time series variation in addition to cross-sectional and cross-country variation. This will also permit addressing some endogeneity issues, like the timing of retirement. 


\section{References}

Banca d'Italia (1999), Relazione Annuale, May 1999, Rome.

Banks, J., R. Blundell, and A. Brugiavini (2001), "Risk Pooling, Precautionary Saving and Consumption Growth", The Review of Economic Studies 68, 757-779.

Barsky, R.B., F.T. Juster, M.S. Kimball, and M.D. Shapiro (1997), "Preference Parameters and Behavioral Heterogeneity: An experimental Approach in the Health and Retirement Study," Quarterly Journal of Economics 112, 537-579.

Beltrametti, L. (1996), Il debito pensionistico in Italia, Bologna: Il Mulino.

Benartzi and Thaler (2001), "Naïve Diversification Strategies in Defined Contribution Saving Plans", American Economic Review 91, 79-98.

Bernheim B.D., J. Skinner, and S. Weinberg (2001), "What accounts for the Variation in Retirement Wealth Among U.S. Households?," American Economic Review 91, 832-857.

Bernheim, B.D. (1999), “Taxation and Saving”, forthcoming in: A.J. Auerbach and M. Feldstein (eds.), Handbook of Public Economics, Elsevier Science Publishers.

Bertaut, Carol and Martha Starr-McCluer (2000), "Household Portfolios in the United States.” Mimeo, Federal Reserve Board of Governors, April 2000.

Blöndal, S. and S. Scarpetta (1998), "The retirement decision in OECD countries. OECD Economics Department Working Paper no. 202.

Board of OASI Trustees (2001). "The 2001 Annual Report of the Board of Trustees of the Federal Old-Age and Survivors Insurance and Disability Insurance Trust Funds." Washington, D.C., March 19, 2001.

Browning, M., and A. Lusardi (1996), "Household Saving: Micro Theories and Micro Facts," Journal of Economic Literature 34, 1797-1855.

Brugiavini, A. (1999), "Social Security and Retirement in Italy", in: Gruber, J., and D.A. Wise (eds.) Social Security and Retirement around the World, Chicago University Press, 181-237.

Carroll, C.D. (1992), “The Buffer-Stock Theory of Saving: Some Macroeconomic Evidence," Brookings Papers on Economic Activity 2, 61-156.

Carroll, C.D. (1997), "Buffer Stock Saving and the Life Cycle/Permanent Income Hypothesis," Quarterly Journal of Economics 112, 3-55.

Carroll, C.D. (2001), "Portfolios of the Rich", in: Guiso, L., M. Haliassos, and T. Jappelli (eds.), Household Portfolios, MIT-Press, 389-429.

Copeland, Craig (2001), "IRA Assets Continue to Grow." Employee Benefit Research Institute, EBRI Notes Vol. 22 No. 1 (January 2001).

De Nederlandsche Bank (2000), Het Bancaire Hyptheekbedrijf Onder de Loep. De Nederlandsche Bank, Amsterdam, Netherlands.

Deaton, A. (1991), “Saving and Liquidity Constraints,” Econometrica 59, 1221-1248. 
Department of Labor (2001), “Abstract of 1997 Form 5500 Annual Reports.” Private Pension Plan Bulletin, Number 10, Winter 2001, U.S. Department of Labor, Pension and Welfare Benefits Administration, Office of Policy and Research.

Dynan, K.E. (1993), “How Prudent are Consumers?”, Journal of Political Economy 101, 1104-1113.

Engen, E.M., W.G. Gale, and J.K. Scholz (1996), The Illusory Effects of Saving Incentives on Saving", Journal of Economic Perspectives 10, 113-138.

Federal Reserve (2001), Flow of Funds Accounts of the United States: Fourth Quarter 2000. Board of Governors of the Federal Reserve System, Washington DC 20551. See http://www.federalreserve.gov/releases/Z1.

Feldstein, M. (1974), "Social Security, Induced Retirement, and Aggregate Capital Accumulation”, Journal of Political Economy 82, 905-926.

Franco, Daniele. 2000. "Italy: A Never-Ending Pension Reform." Presented at the NBER-Kiel Institute Conference, Berlin, March 20-21, 2000.

Gollier, C. (2001), The Economics of Risk and Time, Cambridge Mass: MIT Press.

Gollier, C., and J.W. Pratt (1996), "Risk Vulnerability and the Tempering Effect of Background Risk,” Econometrica 64, 1109-1124.

Gruber, J., and D.A. Wise (eds.) (1999), Social Security and Retirement around the World, Chicago University Press.

Guiso, L., and M. Paiella (2001), "Risk Aversion, Wealth and Background Risk", CEPR Discussion Paper 2728.

Guiso, L., P. Sapienza, and L Zingales (2000), “The Role of Social Capital in Financial Development", NBER Working Paper 7563.

Guiso, L., T. Jappelli, and D. Terlizzese (1992), "Earnings Uncertainty and Precautionary Saving”, Journal of Monetary Economics 30, 307-337.

Guiso, L., T. Jappelli, and D. Terlizzese (1996), "Income Risk, Borrowing Constraints, and Portfolio Choice," American Economic Review 86, 158-172.

Guiso, L., T. Jappelli, and L. Pistaferri (1999), "What determines earnings and employment uncertainty?," CEPR Discussion Paper 2043.

Gustman, A.L., and T.L. Steinmeier (1994), "Retirement in a Family Context: A Structural Model for Husbands and Wives”, NBER Working Paper 4629.

Gustman, A.L., and T.L. Steinmeier (1998), "Effects of Pensions on Savings: Analysis with Data from the Health and Retirement Study," NBER Working Paper 6681.

Gustman, A.L., and T.L. Steinmeier (1999), "What People Don't Know about their Pensions and Social Security: An Analysis using Linked Data from the Health and Retirement Study," Dartmouth College Working Paper 99-11.

Haliassos, M. and C.C. Bertaut (1995), "Why do so Few Hold Stocks?", The Economic Journal 105, 1110-1129.

Hochgürtel, S. (1998), Household Portfolio Choices, Ph.D. thesis, Tilburg University.

Hubbard, G.R., J. Skinner, S.P. Zeldes (1995), "Precautionary Saving and Social Insurance", Journal of Political Economy 103, 360-399. 
Hubbard, G.R., J. Skinner, S.P. Zeldes (1994a), “The Importance of Precautionary Motives in Explaining Individual and Aggregate Saving”, Carnegie-Rochester Conference Series in Public Policy 40, 59-125.

Hubbard, G.R., J. Skinner, S.P. Zeldes (1994b), "Expanding the Life-Cycle Model: Precautionary Saving and Public Policy", American Economic Review 84, 174-179.

Hurd, M.D. (2001), "Portfolio Holdings of the Elderly," in: Guiso, L., M. Haliassos, and T. Jappelli (eds.), Household Portfolios, MIT-Press, 431-472.

Hurd, M.D., L. Lillard, and C. Panis (1998) "An Analysis of the Choice to Cash Out Pension Rights at Job Change or Retirement," RAND DRU-1979-DOL.

Johnson, P. (1999), (ed.), Older Getting Wiser, IFS.

Kapteyn, A. and K. de Vos (1999), "Social Security and Retirement in The Netherlands", in: Gruber, J., and D.A. Wise (eds.) Social Security and Retirement around the World, Chicago University Press, 269-303.

Kapteyn, A. and C. Panis (2002). "The Size and Composition of Wealth Holdings in the United States, Italy, and the Netherlands.” RAND DRU-2767-DOL, March 2002.

Kimball, M.S. (1990), "Precautionary Saving in the Small and in the Large," Econometrica 58, 53-73.

Kimball, M.S. (1993), “Standard Risk Aversion”, Econometrica 61, 589-611.

King, M. A. and J.I. Leape (1998), "Wealth and Portfolio Composition: Theory and Evidence", Journal of Public Economics 69, 155-193.

Lusardi, A. (1997), "Precautionary Saving and Subjective Earnings Variance”, Economics Letters 57, 319-326.

Maestas, N. (2001), "Labor, Love and Leisure: Complementarity and the Timing of Retirement by Working Couples," mimeo, Department of Economics, UC Berkeley.

Modigliani, F., and R. Brumberg (1954), "Utility analysis and the consumption function: An interpretation of the cross-section Data," in K. Kurihara (ed.), Post-Keynesian Economics (388-436). New Brunswick: Rutgers University Press.

Paxson, C. (1990), "Borrowing Constraints and Portfolio Choice”, Quarterly Journal of Economics 105, 535-543.

Rostagno, M. (1996), Il percorso della riforma, 1992-1995: Nuovi indicatori di consistenza e di sostenibilità per il Fondo Pensioni Lavoratori Dipendenti. Rome: Banca d'Italia.

Scott, Jason and John Shoven (1996), "Lump Sum Distributions: Fulfilling the Portability Promise or Eroding Retirement Security?”, EBRI Issue Brief, Washington DC: Employee Benefit Research Institute, October.

Social Insurance Bank (2000), Bedragen AOW per 1 januari 2001, The Hague.

Venti, S.F. and D.A. Wise (1990), "Have IRAs Increased U.S. Saving: Evidence from Consumer Expenditure Surveys" Quarterly Journal of Economics 105, 661-698.

Venti, S.F. and D.A. Wise (1991), "The Saving Effect of Tax-Deferred Retirement Accounts: Evidence from the SIPP”, in: B.D. Bernheim and J.B. Shoven (eds.) 
National Saving and Economic Performance, University of Chicago Press, Chicago.

Venti, S.F. and D.A. Wise (1995), Individual Response of Retirement Savings Programs: Results from U.S. Panel Data, Ricerche Economiche.

Vissing Jørgensen, A. (2000), "Towards an Explanation of Household Portfolio Choice heterogeneity: Nonfinancial Income and Participation Cost Structures", Working paper, department of economics, University of Chicago.

Zweimüller, J., R. Winter-Ebmer (1996), "Retirement of Spouses and Social Security Reform”, European Economic Review 40, 449-472. 